\title{
MEMORIAL DE TÍTULOS APRESENTADO PARA PROMOÇÃO DOCENTE À CLASSE E DA UNIVERSIDADE FEDERAL DE SANTA MARIA
}

http://dx.doi.org/10.5902/2318133867494

\author{
Ana Fátima Viero Badaró ${ }^{1}$
}

Resumo

Memorial elaborado por Ana Fátima Viero Badaró, fisioterapeuta, docente do Departamento de Fisioterapia e Reabilitação, do Centro de Ciências da Saúde, da Universidade Federal de Santa Maria - UFSM -, para promoção à Classe E - professor titular -, de acordo com o estabelecido pela resolução n. 013/2014 da UFSM. As atividades docentes, referentes ao ensino, a pesquisa, a extensão e a administração, foram consideradas no período entre 2008-2018. O memorial foi apresentado em fevereiro de 2020, defendido e aprovado em 13 janeiro de 2021.

Palavras-chave: professor do ensino superior; fisioterapia; educação em saúde.

\section{MEMORIAL OF TITLES PRESENTED FOR TEACHING PROMOTION TO THE CLASS E OF THE FEDERAL UNIVERSITY OF SANTA MARIA}

\begin{abstract}
Memorial presented by Ana Fátima Viero Badaró, physiotherapist, professor at the Department of Physiotherapy and Rehabilitation, Health Sciences Center, Federal University of Santa Maria UFSM -, for promotion to Class E - titular professor -, as established by resolution n. 013/2014 of UFSM. The teaching activities, related to teaching, research, extension and administration, were considered in the period between 2008-2018. The memorial was presented in February 2020 and defended and approved on January 13, 2021.

Key-words: professor' university; physical therapy specialty; health education.
\end{abstract}

${ }^{1}$ Universidade Federal de Santa Maria, Brasil. E-mail: badaroana@uol.com.br. 


\section{Introdução}

presentar esse memorial tem um significado, para mim, muito além das
expectativas docente para evolução na carreira do magistério superior. Custei
muito a me decidir por fazê-lo, na angústia de não ter concluído tudo o que poderia e gostaria de fazer. Mas o incentivo de colegas e o acompanhamento de outras defesas me encorajaram a iniciar esse processo.

Foi difícil reviver o passado, uma vez que relembrar os momentos de sucesso só nos traz alegrias, porém os de dificuldades e perdas ainda nos causam dor. Nessa caminhada muitos entes queridos já nos deixaram, como familiares, colegas, amigos. Houve as conquistas de classe, a afirmação da profissão no cenário nacional da saúde, as dificuldades pessoais físicas e financeiras para se manter em atividade, entre outras. Mas tudo já passou e, depois da catarse, consegui concluir esse memorial, que ora apresento.

O referido memorial segue os requisitos estabelecidos pela resolução n. 013/2014, a qual dispõe sobre os critérios para avaliação de docente da carreira do magistério superior com vistas à promoção para a Classe $E$, denominada de professor titular do quadro permanente da Universidade Federal de Santa Maria.

Iniciarei com um breve histórico da minha origem familiar, sobre a formação em Fisioterapia, a respeito do início na profissão e a caminhada para chegar à docência nesta Universidade, com o intuito de apresentar como foi meu aprendizado e minhas vivências e como esses alicerçaram a minha prática docente. Na sequência, o texto será estruturado seguindo a resolução n. 013/2014, procurando demonstrar e considerar as atividades de ensino, pesquisa, extensão, gestão acadêmica e produções profissionais relevantes, no período de 2008-2018.

Embora esteja previsto, no adendo da resolução n. 013/2014, que devam ser consideradas somente as atividades no período de dez anos, agreguei em meu histórico alguns relatos anteriores, os quais considero terem sido importantes na minha trajetória profissional. Ainda, ao relatar as produções realizadas de 2008 a 2018, farei algumas inserções das produções que antecederam esse período, no intuito de demonstrar as relações históricas da evolução atingida nessa década.

Para a compreensão do trabalho docente realizado nestes últimos dez anos, é interessante acompanhar a trajetória acadêmica percorrida nos trinta anos anteriores e constatar a consequente repercussão das escolhas e das realizações conquistadas nesta última etapa da minha profissão na carreira docente.

\section{Minha origem}

Nascida na cidade de Santiago/RS, em 30 de julho de 1955, filha primogênita de Erasmo Alves Badaró, militar do Exército, natural do Estado de São Paulo - filho de emigrantes dos Estados da Bahia, paterno, e de Minas Gerais, materna, - e de Elsa Angela Viero Badaró, natural de Santiago, filha de imigrantes italianos. Em dezembro de 1956 nasceu minha irmã, Maria Leonídia Viero Badaró, a qual, depois de casada com parente, passou a assinar Maria Leonídia Badaró Viero. No ano seguinte ao seu nascimento nos mudamos para a cidade de Santos/SP e, em setembro de 1958, nasceu meu irmão Emilio Basílio Viero Badaró. Em 1959 mudamo-nos novamente para São Paulo capital, quando passamos a conviver, de forma direta, com a família do meu pai, que, para a época, era relativamente pequena e unida: 5 irmãos, uma irmã, cônjuges e

\begin{tabular}{|l|l|l|l|l|l|}
\hline Regae: Rev. Gest. Aval. Educ. & Santa Maria & v. 10 & n. especial & e67494, p. 1-46 & 2021 \\
\hline
\end{tabular}


inúmeros primos. Em 1962, com minha mãe grávida novamente, fomos para Santiago/RS, onde passamos seis meses com a família dela, que ajudou a cuidar de nós com o nascimento do meu outro irmão, Eduardo Antonio Viero Badaró. Nesse período meu pai continuou trabalhando em São Paulo e vinha nos visitar.

Nos anos 1960 a convivência com a família paterna e as visitas periódicas ao Sul, à família materna, me proporcionaram convivências com diversidades culturais, entre os Estados do Sul e do Sudeste. Mais tarde isso foi fundamental como suporte para a transição entre a formação acadêmica realizada em São Paulo e o exercício profissional no Rio Grande do Sul. Naquela época não imaginava que este seria um aspecto frequente em minha vida: estar sempre em movimento para ficar próxima à família, uma vez que parte dela continuava morando em São Paulo e outra parte aqui no Sul.

Maria Leonídia, casada com Jorge Viero, moram em Santiago, tiveram três filhas, Karen, Caroline e Juliana, com as quais convivo desde a gestação até os dias de hoje, de forma muito próxima. Eduardo, casado com Denise Carneiro Badaró, mora em Campinas/SP. Eles têm um casal de filhos, Natália e Lucas, com os quais a distância me priva de uma convivência física mais próxima, contudo o que não altera nossos laços afetivos. Caroline é casada com Marcos Kerpel e tem dois meninos, Marco Antonio e Matheus Humberto. Karen tem uma filha, Isadora. Natália está grávida da Giovana. Emílio mora com minha mãe em Campinas. Essa é a minha família, com os quais me divido entre Santa Maria/RS e Campinas/SP, para manter o convívio familiar, que nos dá suporte para realizar nossos objetivos profissionais.

\section{O caminho para chegar à universidade}

$\mathrm{Na}$ década de 1970 realizamos várias mudanças de cidade, em decorrência da carreira militar de meu pai. Assim, minha formação, no ensino fundamental, iniciou na cidade de São Paulo, capital, cursando o antigo primário, quatro primeiros anos iniciais, depois fomos para São José do Rio Preto/SP, onde concluí o antigo ginásio, os quatro anos seguintes. Após isso mudamo-nos para Boa Vista/RR, onde fiz o primeiro ano do colegial, vindo para Santiago/RS cursar o segundo ano e, após, mudando novamente, para a cidade de Lins/SP, na qual ficamos apenas seis meses quando, mais uma vez, mudamo-nos para a cidade de Campinas/SP, onde concluí o ensino médio e ingressei na Pontifícia Universidade Católica de Campinas - PUCCamp - para cursar Fisioterapia (1976-1978).

Iniciei o curso sem ter a real noção do que seria essa profissão, nem o que essa formação poderia me proporcionar. Naquela época a fisioterapia não era conhecida e sua prática era confundida com a de massagista. O curso era de formação em três anos. Alguns professores fisioterapeutas atuavam na cidade e outros vinham da cidade de São Paulo, trazendo-nos as experiências vindas de suas formações na Universidade de São Paulo - USP - e na Universidade Federal de Minas Gerais - UFMG. Desse modo, nosso aprendizado em fisioterapia era o que tinha de mais atual, na época, no Brasil.

Nos dois primeiros anos do curso trabalhei na secretaria de emissão de diplomas, da PUCCamp. Nesse emprego, além do salário, recebia um auxílio para o pagamento das mensalidades. No terceiro ano deixei de trabalhar para realizar os estágios curriculares e extracurriculares, além dos cursos de capacitação. Meu estágio extracurricular foi realizado na Clínica de Reabilitação do Sanatório Ismael na cidade de Amparo/SP. Foi um 
período muito extenuante, mas de muito aprendizado. Tínhamos aula e estágio em Campinas, no turno da manhã, e, à tarde, um grupo de oito colegas viajávamos para Amparo/SP, retornando à noite.

Nossa turma, junto com um corpo docente jovem e desbravador, era muito envolvida com as questões de classe, pois a Fisioterapia era uma profissão emergente e carecia de um grande empenho para sua estruturação. O reconhecimento da profissão era recente decreto-lei n. 938, de 13 de outubro de 1969, e sua regulamentação, por lei federal, data de 1975 - decreto-lei n. 6.316/75 -, que também criou os Conselho Federal e os conselhos regionais de Fisioterapia e Terapia Ocupacional.

\section{O início das atividades na profissão}

Após a conclusão do curso trabalhei um ano na cidade de São Paulo, iniciando minha atuação profissional, como fisioterapeuta, em 1979, na Associação de Assistência à Criança Deficiente - AACD. Os atendimentos eram ambulatoriais, nas clínicas de neurologia e de ortopedia, em reabilitação motora de crianças portadoras de sequelas neurológicas, decorrentes da mielomeningocele e, também, com pacientes com distrofia muscular progressiva de Duchene.

Essa época foi muito importante para minha carreira, já que foi nesse período que vivenciei intensamente a prática da reabilitação, do trabalho em equipe multidisciplinar, atuando, de forma conjunta com os profissionais fisioterapeutas mais experientes, com os iniciantes, como eu, e com os outros profissionais da área da saúde, como cirurgiões, ortopedistas, neurologistas, psicólogos, enfermeiras, assistentes sociais, técnicos protéticos e técnicos auxiliares da reabilitação. Naquele momento atuavam na fisioterapia muitos técnicos, que foram os precursores da profissão, formados antes da regulamentação para nível superior. Essa integração multiprofissional me proporcionou a base para compreender o paciente nas suas distintas dimensões, quais sejam: físicas, psíquicas, familiar e social, com um olhar mais humanizado para a pessoa portadora de dificuldades físicas.

Nos primeiros meses do ano de 1980 passei a trabalhar na Clínica de Reabilitação do Instituto Nacional de Assistência Médica e Previdência Social, na cidade de Osasco/SP. Nesse curto espaço de tempo, junto com o colega fisioterapeuta Claudio Luvizaro, demos início ao Serviço de Fisioterapia dessa instituição. Em seguida vim para o Sul, para assumir o ensino no curso de Fisioterapia do Centro de Ciências da Saúde da UFSM, ao qual passei a me dedicar intensamente, construindo minha carreira docente. Aqui aperfeiçoei minha formação, solidifiquei residência, fiz grandes vínculos de amizade, exerci, com muita satisfação, a docência na fisioterapia, realizando conquistas e alcançando reconhecimento na profissão.

Em Santa Maria/RS, além da docência, iniciei em 1983 o trabalho em consultório de fisioterapia, no atendimento em reabilitação ortopédica, com atuação, mais especificamente, ao tratamento dos distúrbios da coluna vertebral. Em decorrência disso surgiu a necessidade de aperfeiçoamento em técnicas que visassem o corpo como um todo, e não somente parte dele, como era visto até então. Foi quando iniciei os cursos de 
abordagem corporal globalizada, modalidade inovadora para a fisioterapia da época. A prática, como profissional liberal, no atendimento fisioterapêutico ambulatorial trouxe-me experiências que deram suporte para continuar a exercer o ensino da fisioterapia. Mais tarde, abandonei a prática liberal e me dediquei, exclusivamente, ao ensino na UFSM.

\section{Formação e carreira}

Em dezembro de 1979 visitei o curso de Fisioterapia da Universidade Federal de Santa Maria após tomar conhecimento, em São Paulo, de que estavam selecionando fisioterapeutas para atuar na docência. Na época os fisioterapeutas, coordenadores do curso, prof. Otavio Marinho Falcão, e a chefe do Departamento de Fisioterapia e Reabilitação, prof ${ }^{a}$ Déa Marinho Falcão, muito gentilmente, apresentaram-me as dependências do curso, o campus universitário, o antigo Hospital Universitário, o ambulatório de Fisioterapia no Hospital Universitário do campus e a proposta curricular do curso, que havia acabado de formar sua primeira turma.

No mês de fevereiro fui chamada para assumir e, em 10 de março de 1980, assinei o contrato temporário como professora colaboradora do curso de Fisioterapia da UFSM, lotada no Departamento de Fisioterapia e Reabilitação, do Centro de Ciências da Saúde. Provisoriamente fiquei na residência das primas Lia Margot e Léa Marilda, na época estudantes, que me acolheram para poder iniciar esse trabalho. Sou grata, também, aos seus pais, Ivo e Maria Viero, por esse apoio.

Iniciei minhas atividades docentes com disciplinas teóricas e com o estágio supervisionado nas áreas de ortopedia-traumatologia e respiratória, no setor hospitalar, ambulatorial e unidade de terapia intensiva, práticas as quais compartilhava com a professora Cleres Russo do Amaral - in memorian -, que também iniciou a docência na mesma época. A professora Cleres veio do Rio de Janeiro e, como eu, também com experiência em centro de reabilitação, mas na área neurológica, vivenciada na Associação Brasileira Beneficente de Reabilitação - ABBR - e em na área respiratória. Nossa parceria em reabilitação ajudou a modificar as perspectivas do curso com a fisioterapia, que era vista de forma mais segmentada, para uma visão mais abrangente das áreas musculoesquelética, respiratória e neurológica. Também iniciou a docência em fisioterapia, nessa mesma época, o colega professor Edson Missau, recém egresso da primeira turma desse curso, com o qual convivo até os dias de hoje na docência da fisioterapia da UFSM, visto que é o atual chefe do Departamento de Fisioterapia e de Reabilitação.

Naquela época não existiam as especialidades na fisioterapia e o professor era generalista, atuando nas diversas áreas da profissão. Ou seja, o profissional tinha que se virar para dar conta de tanta demanda. Ainda, fui desafiada, por falta de docentes, a ministrar a disciplina de Administração Hospitalar. Para isso, contei com ajuda de professores do curso de Administração da UFSM.

A profissão foi, aos poucos, evoluindo e, por meio de muitas lutas de classe, fui recebendo o reconhecimento dos usuários e dos profissionais da saúde com quem trabalhava com maior proximidade. Os fisioterapeutas foram aperfeiçoando seus conhecimentos científicos, através de cursos de curta duração, que era o que tínhamos 
na época. Fui me capacitando na área musculoesquelética, com a qual sempre me identifiquei, com atuação no campo da reabilitação e da prevenção de distúrbios corporais, nas distintas fases do crescimento, desenvolvimento e envelhecimento humano.

O ano de 1980 foi de grandes desafios: além de iniciar ainda jovem a prática docente, sem o preparo adequado para tal, os alunos da segunda turma tinham grandes demandas com os gestores do curso, pois clamavam por melhores condições de ensino e nos solicitavam ajuda para buscar outras perspectivas para a profissão. Ainda, tivemos que nos adaptar ao clima, com invernos rigorosos, para nós, que vínhamos do Sudeste, além da ausência da família, uma vez que meus pais e irmãos continuavam morar em Campinas/SP. Para completar, na instituição, todos os professores colaboradores teriam que fazer concurso para disputar a vaga que estavam ocupando. Realizamos, prof. Edson Missau, profa Cleres Amaral e eu, o concurso, fomos aprovados e ingressamos, nesse mesmo ano, na classe de professor auxiliar de ensino, com carga horária de 40 horas. Ademais, nesse ano, o governo federal instituiu o plano de carreira docente, e todos os professores da classe de auxiliar de ensino passaram, no ano seguinte, para a classe de professor assistente ref. 1.

Em 1986 optei pelo regime de dedicação exclusiva como docente na UFSM, o que não mudou as atividades que vinha realizando no ensino, na pesquisa, na extensão e na gestão. Entretanto, essa opção teve repercussão na elevação de meu salário, o que me possibilitou maior investimento em novos cursos, capacitando-me para maior qualificação da prática docente.

Segui minha progressão horizontal e, em 1989, passei a professor adjunto nível 1, chegando até Adjunto nível 4, em julho de 1995, ficando nesse nível até a conclusão do doutorado, em julho de 2008, quando passei para a classe de professor associado, recentemente implantada na carreira docente.

Quadro 1 -

Carreira docente.

\begin{tabular}{|c|c|}
\hline Nível & Período \\
\hline Professor associado & Jul. 2010 - atual \\
\hline Professor adjunto & Jul. 1989 - jul. 2010 \\
\hline Professor assistente & Jan. $1981-$ jul. 1989 \\
\hline Professor auxiliar & $15 / 08 / 1980-$ jan. 1981 \\
\hline Professor colaborador & $10 / 03 / 1980-14 / 08 / 1980$ \\
\hline
\end{tabular}

Fonte: autora (2019).

A fisioterapia evoluía consideravelmente no início dos anos 1980, com as áreas clínicas se configurando em especializações. Em nosso curso sentíamos a necessidade de capacitar os docentes a nível de especialização, mas, na época, as possibilidades eram somente em áreas afins. Como profissão nova, havia o empenho em realizar cursos e proporcionar capacitação para a comunidade acadêmica local e regional. Contudo, 0 que conseguíamos eram as atualizações e aperfeiçoamentos. Assim, meus primeiros dez anos na docência se caracterizaram pela busca e pela realização de cursos e de estágios 
na cidade de São Paulo e, por intermédio desses contatos, trazia para Santa Maria profissionais renomados para palestrar em eventos científicos, ministrar cursos de atualização, capacitando docentes, acadêmicos e egressos da fisioterapia. As áreas emergentes da época eram eletroterapia, cardiorrespiratória e terapia intensiva, neurologia e musculoesquelética. Ajudei a trazer para cá vários profissionais expoentes na fisioterapia da época.

Em 1987 participei, com os fisioterapeutas da cidade, da fundação da Associação Profissional de Fisioterapeutas de Santa Maria e, junto com a UFSM, trouxemos o prof. fisioterapeuta Eduardo Ravagni com o intuito de ministrar um curso, em três módulos de 40 horas, de aperfeiçoamento em Psicomotricidade. Mais tarde esse professor passou a fazer parte do nosso corpo docente, contribuindo muito para a formação e para a qualificação dos acadêmicos e profissionais da fisioterapia.

Em 1988 realizei, na Argentina, o curso de aperfeiçoamento Reeducação Postural Global - RPG -, de 180 horas aula, ministrado pelo prof. francês Philip Souchar. Esse curso foi um divisor de águas na minha formação, pois me fez mudar, radicalmente, a concepção de corpo, até então concebida, na sua segmentação ósteo, muscular, neuro e visceral, para uma visão de totalidade, em que o indivíduo é visto de forma abrangente, um ser bio-psiquico-social, único e indivisível fisicamente. Assim, passei a buscar áreas de conhecimento que auxiliassem a fundamentar essa abordagem e ampliassem o meu entendimento acerca do assunto. Desse modo, minha formação não se restringiu a uma determinada área de concentração, mas na diversidade e na variabilidade de distintas áreas. No quadro 2 é possível se constatar isso a partir das áreas de concentração de minha formação acadêmica.

Quadro 2 -

Titulação, área de concentração e ano de obtenção.

\begin{tabular}{|c|c|c|}
\hline Titulação & Área de concentração & Ano \\
\hline Graduação em Fisioterapia & - & $1976-1979$ \\
\hline Especialização & Saúde Coletiva & $1988-1991$ \\
\hline Mestrado & Educação e Política & $1994-1997$ \\
\hline Doutorado & Ciências da Saúde - Bioética & $2004-2008$ \\
\hline Pós-doutorado & Bioética & 2009 \\
\hline
\end{tabular}

Fonte: autora (2019).

\section{Especialização}

Iniciei um curso de especialização em Porto Alegre. No entanto, após frequentá-lo por um ano, aos finais de semana, vi-me impedida de continuar por problemas econômicos. Era difícil, naquela época, conseguir ajuda financeira institucional para cursos particulares, e com um salário muito instável, as possibilidades de investir na capacitação profissional ficavam limitadas.

No final dos anos 1980, com o advento do Sistema Único de Saúde - SUS -, o Centro de Ciências da Saúde viu também a necessidade de qualificar os docentes na área de Saúde Pública e ofertou o curso de Especialização em Saúde Coletiva, 
destinando, no mínimo, duas vagas para cada curso deste Centro, e as demais para outras instituições da cidade. Então, a professora Maria Saleti Lock Vogth e eu fomos as representantes do curso de Fisioterapia do CCS selecionadas para essas vagas.

Sob a orientação da prof ${ }^{a}$ Scheila Terezinha Mondardo, realizei, juntamente com as colegas enfermeiras Carmem Lúcia Colomé Beck, Mara Regina Caino Teixeira e Thais Grassi Didonet Dalmolin, a monografia intitulada Investigação da força de trabalho dos enfermeiros e fisioterapeutas de Santa Maria/RS, concluída em janeiro de 1991.

Essa formação me possibilitou a abertura de novos horizontes para a fisioterapia, passei a trabalhar com o novo modelo de saúde pública, ampliando os campos da nossa atuação. Assim, as atividades extensionistas que já realizava no curso foram fortalecidas, o que facilitou o cumprimento da obrigatoriedade delas a partir da Reforma Curricular de 1993.

Os colegas docentes do curso, após organizarmos e realizarmos inúmeros cursos de aperfeiçoamento, fizeram o Curso de Especialização em Fisioterapia para a própria capacitação. Não participei desse evento por estar envolvida com outras atividades.

\section{Mestrado}

Fui instigada a realizar o Mestrado por sentir necessidade de aprimorar as questões do ensino em saúde e, também, por estímulo à progressão na carreira docente. $\mathrm{Na}$ fisioterapia não tínhamos mestrado na área. Tentávamos buscar em áreas afins, mas o reduzido número de docentes no curso era impedimento para afastamentos mais longos. Nesse contexto surgiu uma oportunidade no Centro de Educação da UFSM, o qual aceitava profissionais da saúde como candidatos. Fui apresentada à prof ${ }^{\mathrm{a}} \mathrm{dr}^{\mathrm{a}}$ Maria Arlete Pereira, pela colega fisioterapeuta profa Nara Maria Severo Ferraz, que já estava realizando seu mestrado nesse centro.

A profa Artelh trabalhava com políticas em educação e consegui, a partir da monografia realizada em Saúde Coletiva, somada às práticas assistenciais da fisioterapia na área musculoesquelética, apresentar a proposta para estudar os problemas de saúde do trabalhador, referente a lesões por esforços repetitivos - LER. Assim, fui aceita na seleção do mestrado. Realizei essa pós-graduação sem afastamento, apenas com reorganização da carga horária a ser ministrada no curso. Confesso que esse foi o curso mais difícil que fiz, pois não foi fácil mudar o discurso da área da saúde, positivista, para um discurso dialético da educação, de modo a associar essas duas áreas para um trabalho inovador. Mas sempre há um anjo para nos socorrer e a amiga Maria Angélica Villagran - in memorian - me sugeriu trabalhar com a teoria de Paulo Freire ao fazer a análise dos meus dados. Desse modo, em 1996, conclui a dissertação de mestrado Conscientização corporal do trabalhador bancário: um estudo de caso.

Esse estudo gerou grandes mudanças para os bancários com os quais realizei a pesquisa, desde o autocuidado corporal, a sensibilização dos gestores para providenciar mudanças na ergonomia dos mobiliários de trabalho, até a maior tolerância com os problemas de saúde acarretados pela LER. Minha pesquisa repercutiu na classe desses trabalhadores por meio do envolvimento do Sindicato dos Bancários, que se empenhou em divulgar os cuidados, para com a saúde deles, utilizando, dentre outros referenciais, 
minha dissertação. No curso de Fisioterapia colaborei para o avanço no que se refere às ações em saúde do trabalhador, por meio do incentivo às práticas extensionistas de ensino, entre diversas categorias de trabalhadores, visando à educação, à promoção, à prevenção e à assistência na saúde dessa população.

Ao término do Mestrado, após apresentar o trabalho no evento da SBPC, em 1998, na cidade de Natal/RN, sofri um acidente, por atropelamento, que resultou em uma lesão de fratura do braço direito, com complicações neurológicas. Em função disso tive de me afastar das atividades docentes por quase três anos. $O$ tratamento continuou, voltei, de forma gradativa às atividades de ensino e, aos poucos, fui retomando as funções anteriores, além do ensino em sala de aula.

\section{Doutorado}

O Doutorado também aconteceu após muitas tentativas frustradas do Departamento em trazer um curso de pós-graduação stricto sensu. Com o incentivo institucional para os cursos capacitarem seus docentes, por intermédio de convênios com instituições renomadas, conseguimos realizar, com a Universidade de Brasília, essa parceria. Assim, novamente, alguns docentes da fisioterapia, que já tinham concluído o seu mestrado, envolveram-se na organização e puderam ingressar no doutorado pelo Programa de Qualificação Interinstitucional, conveniado com o Centro de Ciências da Saúde da UnB e o Departamento de Fisioterapia e Reabilitação da UFSM. As possibilidades das áreas de concentração eram variadas e cada uma das candidatas puderam se inserir naquelas em que vinham atuando na fisioterapia. Participaram desse programa as colegas: Ana Lucia Cervi Prado, Claudia Moraes Trevisan, Elhane Glass Morari Cassol, Maria Saleti Lock Vogt, Marisa Pereira Gonçalves, Nara Maria Severo Ferraz.

A minha escolha da área de concentração em Bioética, no doutorado, decorreu em virtude de estar engajada ao Comitê de Ética em Pesquisa do CCS desde 1997. Esse foi o primeiro CEP da nossa instituição. Já havia realizado um curso de aperfeiçoamento em Bioética, em Porto Alegre/RS e me encantei com esses estudos. Para conspirar a meu favor, na UnB, existiam dois docentes renomados trabalhando nessa área, o prof. dr. Volnei Garrafa e a prof ${ }^{a}{ } r^{a}$ Dirce Guilhem, a qual tinha vaga para orientação e me aceitou como orientanda.

A partir de minha aprovação foram quatro anos de estudos focados na Ética e na Bioética, com idas e vindas a Brasília/DF, com afastamento parcial. Nos últimos dois anos consegui afastamento total para concluir a tese, intitulada Ética e bioética na práxis da fisioterapia, em que realizei o estudo com fisioterapeutas que exerciam sua atuação profissional em Santa Maria/RS, investigando seus conhecimentos sobre Ética e Bioética. Foi um estudo muito prazeroso, que me fez rever toda a história da fisioterapia no Brasil e no mundo, e ver como a Ética estava inserida em suas discussões e publicações. Também foi a possibilidade de reencontrar ex-alunos, os quais participaram da amostra de minha pesquisa, de ser recebida com carinho por todos, o que me sensibilizou muito.

Com esse estudo passei a ministrar, no curso de Fisioterapia, a disciplina de Bioética que, com a nova reforma curricular, deveria ser inserida obrigatoriamente na grade de ensino. Ainda, fui informada, por colegas que trabalharam na revisão do código de Ética da Fisioterapia, no Conselho Federal - Coffito -, que minha tese foi utilizada para ajudar nas reflexões acerca de nossa profissão. Ao retornar do doutorado, o CEP/CCS 
havia se integrado ao CEP/UFSM, que estava se organizando com um número muito maior de participantes e com grande demanda de projetos de distintas áreas de conhecimento. Assim, essa formação foi muito importante para realizar a análise dos projetos e as discussões neste grupo.

Ademais, muitos profissionais e estudantes, interessados nesse tema, procuraramme para auxiliar em seus estudos de graduação e de pós-graduação. Trabalhar com a Bioética me levou a uma maior compreensão das ações que envolvem a ética na fisioterapia e também no seu contexto geral, propiciando reflexões críticas e construtivas, antes difíceis de se alcançar. Ampliar esse horizonte me fez crescer como ser humano.

\section{Pós-doutorado}

Participando de um evento de ética em pesquisa, na UFSM, conheci o prof. dr. Miguel Sanchez, da Faculdade de Medicina da Universidade Complutense de Madrid, que trabalha com Bioética. Desse encontro surgiu a oportunidade do pós-doutorado, que

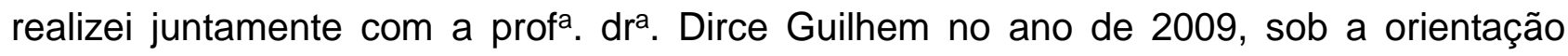
desse professor.

Foram três meses de convivência com os estudos em bioética, assistindo as aulas com os alunos do Mestrado em Bioética, participando dos seminários e das discussões de casos, coordenado pelo prof. dr. Diego Gracia, juntamente com o prof. dr. Miguel Sanchez, a prof ${ }^{a} \mathrm{dr}^{\mathrm{a}}$ Lydia Feito Grande e outros profissionais que ali estudavam. Também participamos de algumas aulas de Bioética para os graduandos em Medicina e de simpósios e congressos de Bioética que ocorreram em distintas instituições na cidade de Madrid.

O pós-doutorado trouxe-me um conhecimento mais amplo, mais abrangente da Bioética, uma vez que me permitiu interagir com profissionais de distintas áreas da saúde e de diferentes nacionalidades. Ainda, possibilitou minha inserção em inúmeros eventos científicos, análises de estudos da área, participação na criação do Comitê de Bioética do Hospital Universitário de Santa Maria - Husm -, além de me fazer voltar a integrar o Comitê de Ética em Pesquisa da UFSM.

\section{Ensino na graduação}

Atuo na docência há 40 anos e sempre tive grande participação no ensino da graduação do curso de Fisioterapia da UFSM, procurando oferecer um ensino de qualidade. Nestes anos de docência participei da formação de quase todos os egressos do curso, apenas no período do meu afastamento de saúde, deixei de acompanhar três turmas. Nosso curso, até essa data, já formou 1.415 fisioterapeutas, que passaram por mim essas várias gerações de alunos, às quais sempre procurei mostrar a importância do estudo, da pesquisa e das atividades extensionistas, as quais extrapolam as fronteiras da sala de aula.

Minha atuação sempre foi na fisioterapia. No início, como generalista, minhas disciplinas foram nas diversas áreas de conhecimento em saúde. No ciclo préprofissionalizante ministrei os conteúdos de recursos físicos utilizados na fisioterapia, anamnese e avaliação física, cinesiologia e cinesioterapia. No ciclo profissionalizante atuei nas área musculoesquelética, nas disciplinas de Fisioterapia Aplicada à Ortopedia, Traumatologia e Reumatologia, com conteúdos teóricos e práticas ambulatorial.

\begin{tabular}{|l|l|l|l|l|l|}
\hline Regae: Rev. Gest. Aval. Educ. & Santa Maria & v. 10 & n. especial & e67494, p. 1-46 & 2021
\end{tabular}


Supervisionei estágios, nessa área, a nível ambulatorial. Já, na área respiratória, com menor tempo de atuação, exerci a docência com prática na internação e no Centro de Terapia Intensiva. No início do curso os estágios ambulatoriais eram realizados no ambulatório do Serviço de Fisioterapia do Husm e os de internação aconteciam no antigo Hospital Universitário e na Clínica Sampar. Posteriormente, com a mudança do Husm para o campus, passamos a realizar todas as nossas aulas práticas no campus, facilitando a interação ensino-assistência.

Cabe destacar que o Ambulatório de Fisioterapia do Husm foi sempre mantido pelos docentes e alunos do curso, com as atividades de ensino. Muitas vezes, nas férias, era oferecido o estágio extracurricular, propiciando aos acadêmicos da fisioterapia uma maior vivência prática e, também, a manutenção da assistência aos pacientes que estavam em tratamento. Além das aulas, orientei monitorias nas disciplinas préprofissionalizantes.

\section{O elenco de disciplinas ministradas na graduação}

Após a legislação passar os cursos de Fisioterapia de três para quatro anos, ocorreu a primeira reforma curricular do curso em 1984, com ampliação da carga horária e o acréscimo de disciplinas vinculadas à saúde pública e à prevenção em saúde. Outra reforma curricular foi feita em 1992 e as monografias foram incluídas na formação acadêmica, para a conclusão do curso. Assim, além das aulas, fui assumindo gradativamente novas atividades, no ensino, na extensão e a pesquisa.

Portanto, com a evolução curricular, passei a assumir novas disciplinas. Na Fisioterapia na Promoção da Saúde, trabalhei com crianças e adolescentes e na Saúde do Trabalhador, juntamente com a colega, prof ${ }^{a}$ Maria Saleti. No núcleo profissionalizante, houve a definição das áreas de fisioterapia cardiorrespiratória, neurológica e musculoesquelética, com disciplinas e estágios próprios. Passei a ministrar, a partir desse momento, as disciplinas de Fisioterapia em Orto-Tramatologia e Reumatologia na área musculoesquelética.

Em 2002 foi promulgada a nova diretriz curricular para os cursos de graduação em Fisioterapia, a qual passou a exigir a inserção dos conhecimentos de Bioética nos currículos. A partir de 2004 houve nova reforma curricular e passei a ministrar as disciplinas de Bioética, Ética e Ética na Pesquisa. Outra reforma ocorreu em 2015 e me foi acrescentada a disciplina de Deontologia, em decorrência da aposentadoria do colega que a ministrava. Com isso, acabei me dedicando às disciplinas pré-profissionalizantes, afastando-me das profissionalizantes. Logo, deixei de ministrar as aulas práticas da área musculoesquelética. No quadro 3, apresento as disciplinas que ministrei no período de 2008-2018. 
Quadro 3 -

Disciplinas ministradas na graduação, no período de 2008 a 2018/19, referentes à dois currículos em transição

\begin{tabular}{|c|c|c|c|c|}
\hline \multicolumn{2}{|r|}{ Disciplinas } & \multirow[t]{2}{*}{ Situação } & \multirow[t]{2}{*}{$\mathrm{CH}^{2}$} & \multirow[t]{2}{*}{ Ano/semestre } \\
\hline Código & Nome & & & \\
\hline \multicolumn{5}{|c|}{ Disciplinas do currículo anterior } \\
\hline FSR1021 & Fisioterapia na Saúde do Escolar & Regular & 60 & $2008 / 2-2015 / 2$ \\
\hline FSR1009 & Bioética & Regular & 30 & $2008 / 2-2015 / 2$ \\
\hline FSR1099 & $\begin{array}{l}\text { Fisioterapia nas Deformidades da } \\
\text { Coluna Vertebral }\end{array}$ & $\mathrm{DCG}^{3}$ & 60 & $\begin{array}{l}2010 / 2 \\
2011 / 2\end{array}$ \\
\hline FSR1042 & Ética na Pesquisa & $\overline{D C G}$ & 30 & $\begin{array}{l}2008 / 2-2010 / 1 \\
2011 / 1\end{array}$ \\
\hline FSR1100 & $\begin{array}{l}\text { Biomecânica da Coluna Vertebral e da } \\
\text { Região Tronco-abdominal }\end{array}$ & DCG & 45 & $\begin{array}{l}2010 / 1-2011 / 1 \\
2012 / 1-2014 / 2 \\
2015 / 1-2015 / 2\end{array}$ \\
\hline FSR1029 & $\begin{array}{llll}\text { Fisioterapia } & \text { em } & \text { Ortopedia } & \text { e } \\
\text { Traumatologia } & & & \\
\end{array}$ & Regular & 30 & $2009 / 2$ \\
\hline FSR1106 & 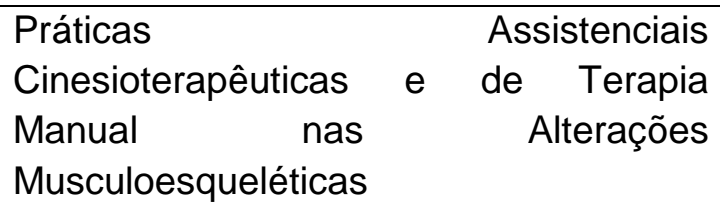 & DCG & 30 & $\begin{array}{l}2011 / 2 \\
2013 / 2\end{array}$ \\
\hline \multicolumn{5}{|c|}{ Disciplinas do currículo vigente } \\
\hline FSR1153 & Fisioterapia em Saúde Escolar & Regular & 45 & $2017 / 2-2019 / 2$ \\
\hline FSR1038 & Estágio Supervisionado I & Regular & 75 & $2016 / 1$ \\
\hline FSR1135 & Biomecânica Articular & Regular & 45 & $\begin{array}{l}2016 / 1-2017 / 2 \\
2018 / 2-2019 / 2\end{array}$ \\
\hline FSR1136 & Bioética & Regular & 30 & $2017 / 2-2019 / 2$ \\
\hline FSR1170 & $\begin{array}{l}\text { Estágio Supervisionado em Fisioterapia } \\
\text { II }\end{array}$ & Regular & 120 & $\begin{array}{l}2016 / 1-2018 / 1- \\
2\end{array}$ \\
\hline FSR1130 & $\begin{array}{l}\text { Deontologia e Ética Profissional na } \\
\text { Fisioterapia }\end{array}$ & Regular & 30 & $2017 / 2-2019 / 2$ \\
\hline
\end{tabular}

Fonte: autora (2019).

\section{Orientação de trabalhos de conclusão de curso}

Das orientações realizadas muitas foram em parceria com outros docentes, o que já caracterizava as ações interdisciplinares que vínhamos desenvolvendo. Procurávamos divulgar os estudos e incentivar os alunos a participarem em diferentes eventos científicos da área, tais como jornadas acadêmicas e pesquisas, congressos de fisioterapia, congressos de saúde pública, de ciências sociais, de extensão, de saúde do trabalhador, do adolescente, entre outros. Assim, iniciamos as publicações em revistas da fisioterapia que iam surgindo.

O trabalho de conclusão de curso - TCC - era uma atividade optativa, que realizávamos com o intuito de qualificar os nossos alunos para a o exercício da pesquisa. Em 2002 foram promulgadas as novas diretrizes curriculares para os cursos de

${ }^{2} \mathrm{CH}$ : carga horária.

${ }^{3}$ DCG: Disciplina Complementar de Graduação. 
graduação em Fisioterapia e os TCCs passaram a ter caráter obrigatório, instituído em nosso curso, com a reforma curricular em 2004. No quadro 4 são apresentados os TCCs em que participei das orientações, organizados em antes de 2008 (1993-2007) e no período de 2008-2018.

Quadro 4 -

Orientação de trabalhos de conclusão de curso até 2008 (1993-2007) e no período 2008-2018

\begin{tabular}{|c|c|c|c|}
\hline Aluno & Título do TCC & Orientação ${ }^{4}$ & Ano \\
\hline \multicolumn{4}{|c|}{ TCCs - período 1993-2007 } \\
\hline SANTOS, G. M. & $\begin{array}{l}\text { Fisioterapia no pós-operatório de lesão } \\
\text { traumática do nervo ulnar }\end{array}$ & $\begin{array}{l}\text { Ana Fátima } \\
\text { Badaró (Or) }\end{array}$ & 1993 \\
\hline SCHWINGEL, G. & $\begin{array}{l}\text { Afecções da coluna vertebral na rotina do } \\
\text { serviço de fisioterapia do Husm }\end{array}$ & $\begin{array}{l}\text { Ana Fátima } \\
\text { Badaró (Or) }\end{array}$ & 1994 \\
\hline $\begin{array}{l}\text { VENDRUSCOLO, } \\
\text { M.T.; } \\
\text { MAHLKE,T.D. }\end{array}$ & $\begin{array}{l}\text { O alongamento muscular na hiperlordose } \\
\text { lombar }\end{array}$ & $\begin{array}{l}\text { Ana Fátima } \\
\text { Badaró (Or) }\end{array}$ & 1995 \\
\hline $\begin{array}{l}\text { AREND, A. C.; } \\
\text { MAGALHÃES, S. }\end{array}$ & $\begin{array}{l}\text { Relação entre escoliose e a função } \\
\text { pulmonar }\end{array}$ & $\begin{array}{l}\text { Ana Fátima } \quad \mathrm{V} . \\
\text { Badaró (Or) } \\
\begin{array}{l}\text { Maria } \quad \text { Elaine } \\
\text { Trevisan (CO) }\end{array}\end{array}$ & 1995 \\
\hline $\begin{array}{l}\text { RODRIGUES, } \\
\text { A.L. } \\
\text { REAL, JR. }\end{array}$ & $\begin{array}{l}\text { A persistência do reflexo tônico cervical } \\
\text { assimétrico na paralisia espástica } \\
\text { moderada e grave e suas repercussões na } \\
\text { coluna vertebral }\end{array}$ & $\begin{array}{l}\text { Claudia } \text { M. Trevisan } \\
\text { (Or) } \\
\text { Ana Fátima V. } \\
\text { Badaró (CO) }\end{array}$ & 1996 \\
\hline ROSSAROLA, G. & $\begin{array}{l}\text { Incidência de lesões por esforços } \\
\text { repetitivos - LER - nos setores de digitação } \\
\text { da UFSM - campus }\end{array}$ & $\begin{array}{l}\text { Ana Fátima } \quad \mathrm{V} . \\
\text { Badaró (Or) }\end{array}$ & 1996 \\
\hline GRASSER, $\mathrm{T}$. & $\begin{array}{l}\text { Estudo retrospectivo de pacientes com } \\
\text { escoliose e cifoescoliose atendidos no } \\
\text { Serviço de Fisioterapia do HUSM }\end{array}$ & $\begin{array}{l}\text { Ana Fátima } \quad \mathrm{V} . \\
\text { Badaró (Or) } \\
\text { Maria Elaine } \\
\text { Trevisan (CO) }\end{array}$ & 1998 \\
\hline PONTES, J. M. & $\begin{array}{l}\text { Cinesioterapia nas alterações joelho valgo e } \\
\text { varo em crianças de } 08 \text { a } 16 \text { anos }\end{array}$ & $\begin{array}{l}\text { Ana Fátima } \\
\text { Badaró (Or) }\end{array}$ & 2001 \\
\hline $\begin{array}{l}\text { FERREIRA, F.; } \\
\text { ALVES, J. }\end{array}$ & $\begin{array}{l}\text { Quantidade de cargas de material escolar } \\
\text { utilizadas pelas crianças das } 3^{a} \text { a } 5^{a} \text { séries } \\
\text { do Ensino Fundamental de Santa Maria }\end{array}$ & $\begin{array}{l}\text { Ana Fátima } \\
\text { Badaró (Or) }\end{array}$ & 2003 \\
\hline PEDRO, V. B. & $\begin{array}{l}\text { Comparação dos movimentos diagonais da } \\
\text { FNP e do tênis na articulação do ombro }\end{array}$ & $\begin{array}{l}\text { Ana Fátima } \\
\text { Badaró (Or) }\end{array}$ & 2005 \\
\hline $\begin{array}{l}\text { HUBBER, A.; } \\
\text { BECHER, D. }\end{array}$ & $\begin{array}{l}\text { Influência da técnica de alongamento por } \\
\text { facilitação neuromuscular proprioceptiva na } \\
\text { flexibilidade em bailarinas }\end{array}$ & $\begin{array}{l}\text { Ana Fátima } \\
\text { Badaró (Or) }\end{array}$ & 2005 \\
\hline ZANCHET, A. C. & $\begin{array}{l}\text { Comparação da sensibilidade ética entre } \\
\text { estudantes de Fisioterapia da UFSM }\end{array}$ & $\begin{array}{l}\text { Ana Fátima } \\
\text { Badaró (Or) }\end{array}$ & 2007 \\
\hline
\end{tabular}

${ }^{4}$ Or: orientador; CO: co-orientador.

Regae: Rev. Gest. Aval. Educ. Santa Maria

v. 10

n. especial

e67494, p. 1-46 


\begin{tabular}{|c|c|c|c|}
\hline & & $\begin{array}{l}\text { Maria } \quad \text { Elaine } \\
\text { Trevisan (CO) }\end{array}$ & \\
\hline \multicolumn{4}{|c|}{ TCCs - Período 2008-2018 } \\
\hline $\begin{array}{l}\text { HAHN, P. T.; } \\
\text { ULGUIN, C. B. }\end{array}$ & $\begin{array}{l}\text { Correlação entre desvios posturais da } \\
\text { coluna vertebral e o posicionamento pélvico } \\
\text { analisado através de radiografia } \\
\text { panorâmica de perfil }\end{array}$ & $\begin{array}{l}\text { Ana Fátima } \\
\text { Badaró (Or) }\end{array}$ & 2010 \\
\hline SANTOS, E. & $\begin{array}{l}\text { Descrição da flexibilidade, IMC e queixas } \\
\text { de dor em crianças em idade escolar }\end{array}$ & $\begin{array}{l}\text { Ana Fátima } \\
\text { Badaró (Or) }\end{array}$ & 2012 \\
\hline MARQUES, T. D. & $\begin{array}{l}\text { Avaliação postural de escolares: revisão } \\
\text { sistemática }\end{array}$ & $\begin{array}{l}\text { Ana Fátima } \\
\text { Badaró (Or) }\end{array}$ & 2012 \\
\hline $\begin{array}{l}\text { NICHELE, L. F. I.; } \\
\text { TURRA, P. }\end{array}$ & $\begin{array}{l}\text { Caracterização do perfil postural de } \\
\text { escolares frequentadores de uma instituição } \\
\text { filantrópica }\end{array}$ & $\begin{array}{l}\text { Ana Fátima } \\
\text { Badaró (Or) }\end{array}$ & 2015 \\
\hline $\begin{array}{l}\text { TREVISAN, M. } \\
\text { T.; } \\
\text { JESUS, A. H. }\end{array}$ & $\begin{array}{l}\text { Tipo de pé e a distribuição de carga } \\
\text { corporal em estudantes universitários }\end{array}$ & $\begin{array}{l}\text { Ana Fátima } \\
\text { Badaró (Or) }\end{array}$ & 2015 \\
\hline DIAS, S. D. & $\begin{array}{l}\text { Análise do desenvolvimento motor de } \\
\text { crianças de } 6 \text { a } 9 \text { anos }\end{array}$ & $\begin{array}{l}\text { Claudia } \text { M. Trevisan } \\
\text { (Or) } \\
\text { Ana Fátima V. } \\
\text { Badaró }(\mathrm{CO})\end{array}$ & 2015 \\
\hline
\end{tabular}

Fonte: autora (2019).

\section{Iniciação científica e extensão}

Meu envolvimento com a pesquisa veio posteriormente aos trabalhos de ensino e de extensão. Inicialmente as pesquisas eram decorrentes de meu envolvimento com a assistência, relatando casos, fazendo revisão de literatura, orientando TCCs, associando o ensino com a extensão e, consequentemente, com a pesquisa. Mais tardiamente passei a me envolver com projetos de pesquisa, sem, no entanto, afastar-me do ensino e da extensão.

Os estudos com os acadêmicos foram sempre estimulados por meio de bolsas e monitorias. Nos anos 1980 orientei monitorias vinculadas às disciplinas préprofissionalizantes. Posteriormente, com recursos da Pró Reitoria de Assuntos Estudantis - Prae -, obtive bolsas de apoio ao ensino pelo projeto Incrementação da assistência fisioterápica das aulas práticas de fisioterapia em orto-traumatologia e reumatologia - $\mathrm{n}$. 6304, de 1998 - 2004 -, em que os acadêmicos bolsistas davam continuidade à assistência fisioterapêutica prestada aos pacientes em atendimentos nas aulas práticas dessas disciplinas.

Também sempre obtive recursos para as bolsas de extensão e de pesquisa e articulava as ações de saúde integrando os acadêmicos no ensino, na pesquisa e na extensão. No quadro 5 pode ser visualizada a relação das orientações realizadas com 0 apoio de bolsas de iniciação científica e de extensão, no período 2008-2018. 
Quadro 5 -

Bolsistas de iniciação científica, de extensão e de ensino (2008-2018).

\begin{tabular}{|c|c|c|c|}
\hline Aluno & Período & Bolsa $^{5}$ & Programa/projeto \\
\hline MACEDO, J. B. & $\begin{array}{l}01 / 06 / 2016 \\
31 / 12 / 2016\end{array}$ & Fiex - CCS & \multirow{2}{*}{$\begin{array}{l}\text { Programa de Fisioterapia no Cuidado } \\
\text { Corporal de Escolares }\end{array}$} \\
\hline NARDI, L. L. D. & $\begin{array}{l}01 / 08 / 2016 \\
31 / 12 / 2016\end{array}$ & Fiex - CCS & \\
\hline BARRETO, S. C. & $\begin{array}{l}01 / 06 / 2015- \\
31 / 12 / 2015\end{array}$ & IC - Husm & $\begin{array}{l}\text { Avaliação da qualidade de vida em } \\
\text { pacientes com escoliose idiopática }\end{array}$ \\
\hline TURRA, P. & $\begin{array}{l}01 / 05 / 2014 \\
31 / 08 / 2014\end{array}$ & Fiex - CCS & \multirow{4}{*}{$\begin{array}{l}\text { Programa de Fisioterapia no Cuidado } \\
\text { Corporal de Escolares }\end{array}$} \\
\hline JESUS, A. H. & $\begin{array}{l}01 / 05 / 2014- \\
31 / 12 / 2014\end{array}$ & Fiex-CCS & \\
\hline MACHADO, L. K. & $\begin{array}{l}01 / 05 / 2014 \\
31 / 12 / 2014\end{array}$ & Fiex - CCS & \\
\hline ABELA, C. F. C. & $\begin{array}{l}01 / 09 / 2014- \\
31 / 12 / 2014\end{array}$ & Fiex - CCS & \\
\hline TURRA, P. & $\begin{array}{l}01 / 05 / 2013 \\
31 / 12 / 2013\end{array}$ & $\begin{array}{l}\text { Fipe Júnior } \\
\text { CCS }\end{array}$ & $\begin{array}{l}\text { Avaliações e acompanhamento do } \\
\text { crescimento e do desenvolvimento } \\
\text { corporal de escolares }\end{array}$ \\
\hline $\begin{array}{l}\text { NICHELLE, L. F. } \\
\text { I. }\end{array}$ & $\begin{array}{l}01 / 05 / 2013- \\
30 / 12 / 2013\end{array}$ & Fiex - CCS & \multirow{4}{*}{$\begin{array}{l}\text { Programa de Fisioterapia no Cuidado } \\
\text { Corporal de Escolares }\end{array}$} \\
\hline DIAS, S. D. & $\begin{array}{l}01 / 05 / 2013- \\
30 / 12 / 2013\end{array}$ & Fiex - CCS & \\
\hline $\begin{array}{l}\text { NICHELLE, L. F. } \\
\text { I. }\end{array}$ & $\begin{array}{l}01 / 05 / 2012- \\
31 / 12 / 2012\end{array}$ & Fiex - CCS & \\
\hline TURRA, P. & $\begin{array}{l}01 / 05 / 2012- \\
31 / 12 / 2012\end{array}$ & Fiex - CCS & \\
\hline
\end{tabular}

Fonte: autora (2019).

\section{Ensino na pós-graduação}

O Curso de Fisioterapia da UFSM sempre almejou inserir a pós-graduação no seu quadro de ensino. Tivemos muitas dificuldades para a implantação, já que havia um corpo docente escasso para tantas demandas e o afastamento para a qualificação era restrito. Os docentes sempre estiveram empenhados em projetos, tentando parceria com outras instituições para trazer a pós-graduação ao nosso curso, mas não obtivemos sucesso.

No ano de 2005 estimulei-me a organizar um curso de especialização para capacitação de egressos, com apoio da Fundação de Apoio à Tecnologia e Ciência Fatec - do qual fui vice-coordenadora, e o prof. Jones E. Agne, coordenador. Foi um curso de edição única que, de certa forma, incentivou os docentes a ministrarem aulas e orientações além da graduação. Nesse curso tive duas orientandas, minha primeira experiência na pós-graduação. A fisioterapeuta Olga Etelvina da Costa Rohde

${ }^{5}$ Fiex: Fundo de Incentivo à Extensão. CCS: Centro de Ciências da Saúde. IC: Iniciação Científica. Fipe: Fundo de Incentivo à Pesquisa. 
desenvolveu o trabalho $A$ relação das fáscias nos métodos de terapia manual e a fisioterapeuta Cátia T. Camargo Coelho pesquisou o tema "Relação das alterações posturais e índice de massa corporal em escolares do ensino fundamental público de Santa Maria/RS.

Posteriormente, após o término de meu Doutorado (2008), continuei me empenhando para realizarmos um curso regular. Com o apoio do prof. dr. Antonio Marcos Vargas da Silva, recém-contratado para exercer a docência na Fisioterapia, conseguimos iniciar o Curso de Especialização em Reabilitação Físico-Motora em 2011, do qual fui coordenadora, e ele vice-coordenador. Esse curso atualmente está sob a coordenação das professoras dra Michelle Saccol e dra Maria Elaine Trevisan, o qual foi fundamental para alavancar os esforços para se iniciar o Mestrado em Reabilitação Funcional em 2015.

Assim, minha trajetória na pós-graduação foi tardia, mas com muito envolvimento. Além da gestão na especialização ministrei várias disciplinas, orientei inúmeras monografias, as quais me proporcionaram diversas publicações em eventos e periódicos científicos. No Mestrado, ministrei disciplinas como professora colaboradora. No quadro 6 apresentam-se as disciplinas ministradas na pós-graduação.

Quadro 6 -

Disciplinas ministradas na pós-graduação no período de 2008 a 2018.

\begin{tabular}{|c|c|c|c|}
\hline \multicolumn{2}{|r|}{ Disciplina } & \multirow[b]{2}{*}{ Curso } & \multirow[b]{2}{*}{ Ano } \\
\hline Código & Nome & & \\
\hline FSR700 & Atualidades Profissionais & \multirow{6}{*}{$\begin{array}{l}\text { PG em } \\
\text { Reabilitação } \\
\text { Físico- } \\
\text { Motora }\end{array}$} & $\begin{array}{l}2011 / 2, \quad 2012 / 2, \\
2013 / 2,2014 / 2\end{array}$ \\
\hline FSR717 & $\begin{array}{lcc}\text { Atividades Práticas em } & \text { Abordagens da } \\
\text { Postura Corporal } & (15 \mathrm{~h})\end{array}$ & & $\begin{array}{ll}2012 / 1, & 2013 / 1 \\
2014 / 1, & 2015 / 1 \\
2016 / 1 & \end{array}$ \\
\hline FSR702 & Bioética e Ética na Pesquisa & & $\begin{array}{lr}2011 / 2 & 2012 / 2 \\
2013 / 2 & 2015 / 2 \\
2016 / 1 & 2018 / 2 \\
2019 / 2 & \end{array}$ \\
\hline FSR715 & Alterações da Postura Corporal (5 h) & & $\begin{array}{ll}2012 / 1 & 2013 / 1 \\
2014 / 1 & 2015 / 1 \\
2016 / 1 & \end{array}$ \\
\hline FSR716 & $\begin{array}{l}\text { Aspectos Clínicos e Terapêuticos da Dor } \\
\text { Musculoesquelética }\end{array}$ & & $\begin{array}{l}2013 / 1 \quad 2014 / 1 \\
2015 / 12016 / 1\end{array}$ \\
\hline FSR718 & $\begin{array}{l}\text { Biomecânica da Coluna Vertebral, suas } \\
\text { Interrelações e Avaliação Funcional } \\
(15 \mathrm{~h})\end{array}$ & & $\begin{array}{l}2011 / 2 \quad 2012 / 2 \\
2013 / 22015 / 2\end{array}$ \\
\hline FSR819 & $\begin{array}{l}\text { Seminário Avançado de Terapia Manual em } \\
\text { Reabilitação }\end{array}$ & PG em & $2016 / 22018 / 2$ \\
\hline FSR815 & Bioética e Ética na Pesquisa $\quad(30 \mathrm{~h})$ & $\begin{array}{l}\text { Reabilitação } \\
\text { Funcional } \\
\text { - Mestrado } \\
\text { Acadêmico }\end{array}$ & $2017 / 12018 / 2$ \\
\hline
\end{tabular}

Fonte: autora (2019). 
O envolvimento com a pós-graduação lato senso me possibilitou uma experiência com a gestão, com participação nos órgãos superiores da Universidade, o contato com outras instituições de ensino em Fisioterapia e Terapia Ocupacional e a aproximação com colegas experientes em diversas especialidades da Fisioterapia, os quais muito contribuíram para ampliar e atualizar os conhecimentos neste curso. Além disso, me envolvi com vários projetos de pesquisas para a realização das monografias dos especializandos. No quadro 7 apresento as monografias que orientei na pós-graduação.

Tabela 7 -

Monografias orientadas na pós-graduação (2008-2018).

\begin{tabular}{|c|c|c|c|}
\hline Aluno & Título da monografia & Orientação ${ }^{6}$ & Ano \\
\hline $\begin{array}{l}\text { MOURA-SILVA, } \\
\text { M. R. O. G.C. }\end{array}$ & $\begin{array}{l}\text { Dor lombar em adolescentes: ocorrências e } \\
\text { características }\end{array}$ & $\begin{array}{l}\text { Ana Fátima } \mathrm{V} . \\
\text { Badaró (Or) }\end{array}$ & 2012 \\
\hline WEBER, L. M. & $\begin{array}{l}\text { Correlação: desvios posturais coluna } \\
\text { vertebral e posicionamento pélvico analisado } \\
\text { através de radiografia perfil: segunda fase }\end{array}$ & $\begin{array}{l}\text { Ana Fátima } \mathrm{V} . \\
\text { Badaró (Or) }\end{array}$ & 2012 \\
\hline $\begin{array}{l}\text { DALLA FAVERA, } \\
\text { J. M. }\end{array}$ & $\begin{array}{l}\text { Características posturais em adolescentes } \\
\text { com leucemia linfóide aguda: estudo de caso }\end{array}$ & $\begin{array}{ll}\text { Ana Beatriz } & \text { C. } \\
\text { Fonseca (Or) } & \\
\text { Ana Fátima } & \text { V. } \\
\text { Badaró (CO) } & \end{array}$ & 2012 \\
\hline ZIMMER, V. I. & $\begin{array}{l}\text { Avaliação estática do posicionamento } \\
\text { escapular em pacientes em período pré- } \\
\text { operatório de reconstrução do manguito } \\
\text { rotador }\end{array}$ & $\begin{array}{l}\text { Ana Fátima } \\
\text { Badaró (Or) }\end{array}$ & 2012 \\
\hline ZULIAN, T. & $\begin{array}{l}\text { Efeito de um programa de exercícios com } \\
\text { bola suíça sobre a flexibilidade de escolares }\end{array}$ & $\begin{array}{l}\text { Ana Fátima } \mathrm{V} . \\
\text { Badaró (Or) }\end{array}$ & 2013 \\
\hline SARTURI, C. A. & $\begin{array}{l}\text { Avaliação da postura corporal de } \\
\text { hemiplégicos através da biofotogrametria }\end{array}$ & $\begin{array}{l}\text { Analu Lopes } \\
\text { Rodrigues (Or) } \\
\text { Ana Fátima V. } \\
\text { Badaró (CO) }\end{array}$ & 2013 \\
\hline $\begin{array}{l}\text { MACHADO, M. } \\
\text { A. }\end{array}$ & $\begin{array}{l}\text { Avaliação e tratamento fisioterapêutico de } \\
\text { escolioses: revisão sistemática }\end{array}$ & $\begin{array}{l}\text { Ana Fátima V. } \\
\text { Badaró (Or) } \\
\text { Cristiane Carpilovsk } \\
\text { (CO) }\end{array}$ & 2013 \\
\hline $\begin{array}{l}\text { SANTOS, S. B. } \\
\text { A. }\end{array}$ & $\begin{array}{l}\text { Análise do alinhamento pélvico na } \\
\text { incontinência urinária de esforço }\end{array}$ & $\begin{array}{ll}\text { Hedioneia } & \text { M.F. } \\
\text { Pivetta (Or) } & \\
\text { Ana Fátima } & \text { V. } \\
\text { Badaró (CO) } & \end{array}$ & 2013 \\
\hline COCCO, V. M. & $\begin{array}{l}\text { Investigação da influência do trabalho infantil } \\
\text { nas afecções da coluna vertebral de } \\
\text { trabalhadores assistidos em um Cerest }\end{array}$ & $\begin{array}{l}\text { Ana Fátima } \\
\text { Badaró (Or) }\end{array}$ & 2014 \\
\hline $\begin{array}{l}\text { NICHELLE, L. F. } \\
\text { I. }\end{array}$ & $\begin{array}{l}\text { Caracterização do perfil postural de } \\
\text { escolares frequentadores de uma instituição } \\
\text { filantrópica }\end{array}$ & $\begin{array}{l}\text { Ana Fátima } \\
\text { Badaró (Or) }\end{array}$ & 2015 \\
\hline
\end{tabular}

${ }^{6}$ Or: orientador; CO: co-orientador.

Regae: Rev. Gest. Aval. Educ. $\quad$ Santa Maria

v. 10

n. especial

e67494, p. 1-46

2021 


\begin{tabular}{|l|l|l|l|l|}
\hline TURRA, P. & $\begin{array}{l}\text { Qualidade de vida de pacientes com } \\
\text { escoliose idiopática }\end{array}$ & $\begin{array}{l}\text { Ana Fátima V. } \\
\text { Badaró (Or) }\end{array}$ & 2015 \\
\hline $\begin{array}{l}\text { JACOBSON, A. A. } \\
\text { A. }\end{array}$ & $\begin{array}{l}\text { Análise da impressão plantar de bailarinas } \\
\text { clássicas }\end{array}$ & $\begin{array}{l}\text { Ana Fátima V. } \\
\text { Badaró (Or) }\end{array}$ & 2015 \\
\hline TAVARES, D. I. & $\begin{array}{l}\text { Aspectos bioéticos nos estudos sobre } \\
\text { postura, equilíbrio e queda em idosos }\end{array}$ & $\begin{array}{l}\text { Ana Fátima V. } \\
\text { Badaró (Or) }\end{array}$ & 2016 \\
\hline JESUS, A. H. & $\begin{array}{l}\text { Tipo de pé e a distribuição de carga corporal } \\
\text { em estudantes universitários }\end{array}$ & $\begin{array}{l}\text { Fernanda Miranda } \\
\text { (Or) } \\
\text { Ana Fátima V. } \\
\text { Badaró (CO) }\end{array}$ & 2017 \\
\hline
\end{tabular}

Fonte: autora (2019).

\section{Produção intelectual: artigos}

Iniciei minhas publicações científicas com o estudo interdisciplinar sobre a escoliose e a função pulmonar, tema do TCC das acadêmicas Silvana Magalhães e Carla Arend, sob minha orientação, com a colaboração das professoras fisioterapeutas Eliane Castilhos Ribeiro e Maria Elaine Trevisan, que atuavam na área cardiorrespiratória. $O$ estudo foi publicado na Revista Fisioterapia e Movimento, no ano de 1995, intitulado Efeitos da escoliose sobre a função pulmonar. Cabe destacar que esse periódico foi uma das primeiras revistas de Fisioterapia no Brasil e estimulou a divulgação dos estudos da profissão.

Após essa publicação foquei meus estudos para a realização do Mestrado em Educação e, posteriormente, afastei-me para o tratamento das lesões decorrentes da fratura do ombro, consequência de um atropelamento. Voltei a divulgar meus estudos somente a partir do ano de 2006, com três artigos publicados no referido ano e outros três em 2007, decorrentes de projetos de ensino, extensão e pesquisa e das orientações de TCCs. Assim, pode-se constatar, que as publicações inicialmente foram tímidas, devido ao meu envolvimento docente com o ensino e a assistência.

Minha produção científica esteve vinculada aos trabalhos assistenciais que desenvolvi na Fisioterapia com as atividades de ensino, as orientações realizadas na graduação - IC, TCC, extensão -, na pós-graduação lato sensu, e com os projetos de pesquisa e de extensão. Participei de uma co-orientação no Mestrado de Distúrbios da Comunicação Humana, da fisioterapeuta Patrícia Girard, orientanda da profa dra Carolina Mezzomo, fonoaudióloga.

A partir de 2008, com a conclusão do Doutorado, as publicações foram mais evidentes, mas sem deixar de associar as pesquisas aos trabalhos de ensino e de extensão que já desenvolvia, junto aos acadêmicos do curso. Cabe destacar que a participação dos alunos, da graduação e da especialização foram fundamentais para a realização desses estudos.

No total, foram publicados 31 artigos. Dessas publicações 23 são do período de 2008 a 2018, divulgadas em 18 revistas com Qualis variado entre A2 e B5. No quadro 8 estão apresentados os artigos, de acordo com o ano, os autores e os periódicos, e no quadro 9 relacionamos o número de artigos publicados por periódicos, com o Qualis das revistas na área de Educação Física ou afim. 
Quadro 8 -

Artigos publicados em periódicos (2008-2018).

\begin{tabular}{|c|c|c|c|}
\hline Ano & Autores & Artigo & Periódico \\
\hline 2008 & $\begin{array}{l}\text { BADARÓ, A. F.; } \\
\text { GUILHEM, D. }\end{array}$ & $\begin{array}{l}\text { Bioética e pesquisa na Fisioterapia: } \\
\text { aproximação e vínculos }\end{array}$ & $\begin{array}{l}\text { Fisioterapia e Pesquisa, } \\
\text { v. } 15, \text { p. } 402-407,2008 .\end{array}$ \\
\hline 2009 & BADARÓ, A. F. & $\begin{array}{l}\text { O desenvolvimento da Bioética e sua } \\
\text { inserção nas profissões da saúde }\end{array}$ & $\begin{array}{l}\text { The FIEP Bulletin, v.79, } \\
\text { p.183-85, 2009. }\end{array}$ \\
\hline 2010 & BADARÓ, A. F. & Autonomia profissional dos fisioterapeutas & 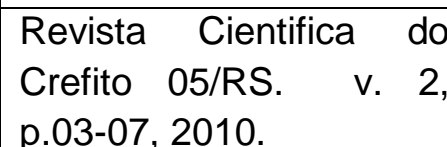 \\
\hline 2011 & $\begin{array}{l}\text { BADARÓ, A. F.; } \\
\text { GUILHEM, D. }\end{array}$ & $\begin{array}{l}\text { Perfil sociodemográfico e profissional de } \\
\text { fisioterapeutas e origem de suas } \\
\text { concepções sobre ética }\end{array}$ & $\begin{array}{l}\text { Fisioterapia } \quad \text { em } \\
\text { Movimento } \quad \text { (PUCPR. } \\
\text { Impresso), v. 24, } \\
\text { p. 445-454, 2011. }\end{array}$ \\
\hline 2011 & $\begin{array}{l}\text { ULGUIM, C. B.; } \\
\text { HAHN, P. T.; } \\
\text { BADARÓ, A. F. }\end{array}$ & $\begin{array}{l}\text { Estudo retrospectivo das curvaturas da } \\
\text { coluna vertebral e do posicionamento } \\
\text { pélvico em imagens radiográficas }\end{array}$ & $\begin{array}{l}\text { Saúde (Santa Maria), v. } \\
37, \text { p. } 29-40,2011 .\end{array}$ \\
\hline 2012 & $\begin{array}{l}\text { BADARÓ, A. F.; } \\
\text { NICHELE, L. F.; } \\
\text { TURRA,P.;ZULI } \\
\text { AN, T. } \\
\text { BASSO, D. B. } \\
\text { A.; } \\
\text { FERNANDES, } \\
\text { D. L.; }\end{array}$ & $\begin{array}{l}\text { Apresentação de um programa de } \\
\text { fisioterapia no cuidado corporal de } \\
\text { escolares }\end{array}$ & $\begin{array}{l}\text { CONVIBRA: Gestão, } \\
\text { educação e promoção } \\
\text { da saúde, v. } 1 \text {, p. } 4271 \text {, } \\
2012 \text {. }\end{array}$ \\
\hline 2012 & $\begin{array}{l}\text { BADARÓ, A. F.; } \\
\text { BASSO, D. A. } \\
\text { B. }\end{array}$ & $\begin{array}{l}\text { A saúde do escolar por um olhar da } \\
\text { fisioterapia }\end{array}$ & $\begin{array}{l}\text { Convibra Saúde, v. 1, p. } \\
4123,2012 .\end{array}$ \\
\hline 2012 & $\begin{array}{l}\text { MACHADO, P. } \\
\text { G.; } \\
\text { MEZZOMO, C. } \\
\text { L.; } \\
\text { BADARÓ, A. F. }\end{array}$ & $\begin{array}{l}\text { A postura corporal e as funções estômato- } \\
\text { gnáticas em crianças respiradoras orais: } \\
\text { revisão de literatura }\end{array}$ & $\begin{array}{l}\text { Revista Cefac (Online), } \\
\text { v. 14, p. 553-565, } 2012 .\end{array}$ \\
\hline 2013 & $\begin{array}{l}\text { ALBUQUERQU } \\
\text { E.I.M.; } \\
\text { POTIGUARA, } \\
\text { M. J.; } \\
\text { TREVISAN, M. } \\
\text { E.; } \\
\text { BADARÓ, A. F.; } \\
\text { PRADO, A. L. } \\
\text { C.; } \\
\text { PASQUALOTT } \\
\text { O,A.S.; } \\
\text { GONÇALVES, } \\
\text { M.P. }\end{array}$ & $\begin{array}{l}\text { Role of physiotherapy in the rehabilitation } \\
\text { of survivors of the Kiss Nightclub tragedy } \\
\text { in Santa Maria, Brazil }\end{array}$ & $\begin{array}{l}\text { Physiotherapy, v. } 99 \text {, } \\
\text { p. } 269-270,2013 .\end{array}$ \\
\hline
\end{tabular}




\begin{tabular}{|c|c|c|c|}
\hline 2013 & $\begin{array}{l}\text { BADARÓ, A. F.; } \\
\text { NICHELE, L. F. } \\
\text { I.; } \\
\text { TURRA, } \\
\text { P.;ZULIAN,T. } \\
\text { BASSO, D.A. } \\
\text { B.; } \\
\text { FERNANDES, } \\
\text { D. L.; }\end{array}$ & $\begin{array}{l}\text { Apresentação de um programa } \\
\text { fisioterapia no cuidado corporal de } \\
\text { escolares: relato de caso }\end{array}$ & $\begin{array}{l}\text { Revista Eletrônica } \\
\text { Gestão \& Saúde, V, } \\
\text { mar/2013, p.2103, 2013. }\end{array}$ \\
\hline 2014 & $\begin{array}{l}\text { SANTOS, S. B. } \\
\text { A; } \\
\text { PIVETTA, H. M. } \\
\text { F.; } \\
\text { BADARÓ, A. F. }\end{array}$ & $\begin{array}{l}\text { Relação entre o alinhamento pélvico e a } \\
\text { incontinência urinária de esforço }\end{array}$ & $\begin{array}{l}\text { Saúde (Santa Maria), } \\
\text { v. } 40, \text { p. } 51-58,2014 .\end{array}$ \\
\hline 2014 & $\begin{array}{l}\text { PIVETTA, H. M. } \\
\text { F.; } \\
\text { VOGT, M. S. L.; } \\
\text { BADARÓ, A. F. }\end{array}$ & $\begin{array}{l}\text { Metodologia do ensino superior: uma } \\
\text { experiência na Pós-graduação lato sensu } \\
\text { em fisioterapia }\end{array}$ & $\begin{array}{l}\text { Cadernos de Educação, } \\
\text { Saúde e Fisioterapia, v. } \\
\text { 1, p. 85-94, } 2014 .\end{array}$ \\
\hline 2014 & $\begin{array}{l}\text { MOURA-SILVA, } \\
\text { M.R. O. G. C.; } \\
\text { BADARÓ, A. F.; } \\
\text { DALL' AGNOL, } \\
\text { M. M }\end{array}$ & $\begin{array}{l}\text { Low back pain in adolescent and } \\
\text { associated factors: a cross sectional study } \\
\text { with schoolchildren }\end{array}$ & $\begin{array}{l}\text { Revista Brasileira de } \\
\text { Fisioterapia, v. } 18, \\
\text { p. } 402-409,2014 .\end{array}$ \\
\hline 2014 & $\begin{array}{l}\text { ZIMMER, V; } \\
\text { BADARÓ, A. F.; } \\
\text { MEEREIS, E. C. } \\
\text { W. }\end{array}$ & $\begin{array}{l}\text { Avaliação estática da posição escapular } \\
\text { de pacientes em pré-operatório do } \\
\text { manguito rotador: estudo de caso }\end{array}$ & $\begin{array}{l}\text { Fisioterapia Ser, v. 9, } \\
\text { p. 48-52, } 2014 .\end{array}$ \\
\hline 2014 & $\begin{array}{l}\text { SARTURI, C. } \\
\text { A.; } \\
\text { RODRIGUES, } \\
\text { A.; } \\
\text { BADARÓ, A. F. }\end{array}$ & $\begin{array}{lccc}\text { Análise da } & \text { postura } & \text { corporal } & \text { de } \\
\text { hemiplégicos } & \text { por } & \text { meio } & \text { da } \\
\text { biofotogrametria: um estudo de caso } & \end{array}$ & $\begin{array}{l}\text { Vittalle, v. 26, p. 21-28, } \\
2014 .\end{array}$ \\
\hline 2015 & $\begin{array}{l}\text { BADARÓ, A. F.; } \\
\text { NICHELE, L. F. } \\
\text { I.; } \\
\text { TURRA, P.; } \\
\text { DIAS, S. D. } \\
\text { GONZALES, X.; } \\
\text { BARRETO, S. } \\
\text { C.; }\end{array}$ & $\begin{array}{l}\text { Reflexões éticas e bioéticas apontadas } \\
\text { nas pesquisas com crianças e } \\
\text { adolescentes }\end{array}$ & $\begin{array}{l}\text { Revista Eletrônica } \\
\text { Gestão \& Saúde. v. 6, } \\
\text { p. 2391-2407, 2015. }\end{array}$ \\
\hline 2015 & $\begin{array}{l}\text { TREVISAN, ME; } \\
\text { ALBUQUERQU } \\
\text { E,I.M.; } \\
\text { BADARÓ, A. F.; } \\
\text { PASQUALOTT } \\
\text { O,A.S.; } \\
\text { GONÇALVES, } \\
\text { M. P.; }\end{array}$ & $\begin{array}{l}\text { Physical therapy performance in the } \\
\text { rehabilitation of survivors of the kiss } \\
\text { nightclub tragedy: an experience report }\end{array}$ & $\begin{array}{l}\text { Fisioterapia em } \\
\text { Movimento (on-line), } \\
\text { v. } 28, \text { p. } 649-655,2015 .\end{array}$ \\
\hline
\end{tabular}




\begin{tabular}{|c|c|c|c|}
\hline & $\begin{array}{l}\text { PRADO, A. L. } \\
\text { C. }\end{array}$ & & \\
\hline 2015 & $\begin{array}{l}\text { BADARÓ, A. F.; } \\
\text { TURRA, P.; } \\
\text { NICHELE, L. F. } \\
\text { I. }\end{array}$ & $\begin{array}{l}\text { Investigação da postura corporal de } \\
\text { escolares em estudos brasileiros }\end{array}$ & $\begin{array}{l}\text { Fisioterapia e Pesquisa } \\
\text { v. 22, p.197-204, } 2015 .\end{array}$ \\
\hline 2015 & $\begin{array}{l}\text { BADARÓ, A. F.; } \\
\text { TURRA, P.; } \\
\text { NICHELE, L. F. } \\
\text { l. }\end{array}$ & $\begin{array}{l}\text { Caracterização da postura corporal de } \\
\text { crianças em situação de vulnerabilidade } \\
\text { social }\end{array}$ & $\begin{array}{l}\text { Revista Neurociências } \\
\text { (Online), v. 23, p. 376- } \\
382,2015 .\end{array}$ \\
\hline 2016 & $\begin{array}{l}\text { MEEREIS, E. C. } \\
\text { W.; } \\
\text { FONSECA, A. } \\
\text { B. C.; } \\
\text { MOTA, C. B.; } \\
\text { BADARÓ, A. F. }\end{array}$ & $\begin{array}{l}\text { Movimentos do balé clássico e alterações } \\
\text { da postura corporal: um breve relato }\end{array}$ & $\begin{array}{l}\text { Revista de Educação } \\
\text { Física - Escola de Ed. } \\
\text { Física do Exército, v. 85, } \\
\text { p. 269-273, 2016. }\end{array}$ \\
\hline 2016 & $\begin{array}{l}\text { NICHELE, L. F. } \\
\text { I.; } \\
\text { BADARÓ, A. } \\
\text { F.; } \\
\text { TURRA, P. }\end{array}$ & $\begin{array}{l}\text { Monitoring of in students body posture: a } \\
\text { longitudinal study }\end{array}$ & $\begin{array}{l}\text { Revista Terapia Manual, } \\
\text { v. } 14 \text {, p. } 313-340,2016 .\end{array}$ \\
\hline 2016 & $\begin{array}{l}\text { BADARÓ, A. F.; } \\
\text { TREVISAN, M. } \\
\text { E.; } \\
\text { ALBUQUERQU } \\
\text { E.I.M.; } \\
\text { PRADO, A. L. } \\
\text { C.; } \\
\text { PASQUALOTO, } \\
\text { A.S.; } \\
\text { GONÇALVES, } \\
\text { M.P. }\end{array}$ & $\begin{array}{l}\text { Avaliação e tratamento fisioterapêutico em } \\
\text { sobreviventes de incêndio: resultados } \\
\text { preliminares }\end{array}$ & $\begin{array}{l}\text { Fisioterapia Brasil, } \\
\text { v. } 17, \text { p. } 41-45,2016 .\end{array}$ \\
\hline 2017 & $\begin{array}{l}\text { TAVARES, D. I.; } \\
\text { BADARÓ, A. F. }\end{array}$ & $\begin{array}{l}\text { Perfil da postura corporal em idosos: } \\
\text { revisão narrativa }\end{array}$ & $\begin{array}{ll}\text { Revista Kairós } & \\
\text { Gerontologia } 20 \quad \text { (n0 } \\
\text { especial 23), p. 101-118 }\end{array}$ \\
\hline 2017 & $\begin{array}{l}\text { TAVARES, D. I.; } \\
\text { STALLBAUM, J. } \\
\text { H.; } \\
\text { PEDROSO, W; } \\
\text { BADARÓ, A. F. }\end{array}$ & $\begin{array}{l}\text { Relação entre o profissional de saúde e o } \\
\text { paciente idoso: questões bioéticas }\end{array}$ & $\begin{array}{l}\text { Vittalle - Revista de } \\
\text { Ciências da Saúde, 29, } \\
\text { n. 2, p. 107-115, 2017. }\end{array}$ \\
\hline \multicolumn{4}{|c|}{ Trabalhos publicados antes de 2008} \\
\hline 1995 & $\begin{array}{l}\text { MAGALHAES, } \\
\text { S.; } \\
\text { AREND, C.; } \\
\text { BADARÓ, A. F.; } \\
\text { TREVISAN, M. } \\
\text { E;. } \\
\text { RIBEIRO, E. C. }\end{array}$ & Efeitos da escoliose na função pulmonar & $\begin{array}{l}\text { Fisioterapia } \quad \text { em } \\
\text { Movimento, v. III, n. 1; p. } \\
\text { 25-31. } 1995\end{array}$ \\
\hline
\end{tabular}




\begin{tabular}{|c|c|c|c|}
\hline 2006 & $\begin{array}{l}\text { BADARÓ, A. F.; } \\
\text { MARCHIORI, } \\
\text { S.; } \\
\text { FARRET, M.; } \\
\text { JURACH, E. }\end{array}$ & $\begin{array}{l}\text { Estudo de alterações dentofaciais na } \\
\text { presença de escoliose idiopática }\end{array}$ & $\begin{array}{l}\text { Jornal Brasileiro de } \\
\text { Ortodontia \& Ortopedia } \\
\text { Facial, } \\
\text { v. } 11, \text { p. } 45-50,2006\end{array}$ \\
\hline 2006 & $\begin{array}{l}\text { FERREIRA, F. } \\
\text { V.; } \\
\text { ALVES, J. S.; } \\
\text { BADARÓ, A. F. }\end{array}$ & $\begin{array}{l}\text { Peso do material escolar utilizado por } \\
\text { escolares da cidade de Santa Maria - RS }\end{array}$ & $\begin{array}{l}\text { Saúde (Santa Maria), v. } \\
\text { 32, p. 39-44, } 2006\end{array}$ \\
\hline 2006 & $\begin{array}{l}\text { SILVA, A. H.; } \\
\text { BECHE, D.; } \\
\text { BADARÓ, A. F. }\end{array}$ & $\begin{array}{l}\text { Relação entre flexibilidade angular do } \\
\text { quadril com a flexibilidade linear da cadeia } \\
\text { muscular posterior }\end{array}$ & $\begin{array}{l}\text { Revista Científica } \\
\text { Jopef, v. } 1 \text {, } \\
\text { p. } 142-145,2006 .\end{array}$ \\
\hline 2007 & $\begin{array}{l}\text { SILVA, A. H.; } \\
\text { BADARÓ, A. F. }\end{array}$ & $\begin{array}{l}\text { Flexibilidade versus alongamento: } \\
\text { esclarecendo as diferenças }\end{array}$ & $\begin{array}{l}\text { Saúde (Santa Maria), } \\
\text { v. } 33, \text { p.32-36 }\end{array}$ \\
\hline 2007 & $\begin{array}{l}\text { SILVA, A. H.; } \\
\text { BADARÓ, A. F. }\end{array}$ & $\begin{array}{l}\text { Relação entre idade e variação da } \\
\text { flexibilidade de bailarinas }\end{array}$ & $\begin{array}{l}\text { Cinergis, v. 8, p. 51-56, } \\
2007 .\end{array}$ \\
\hline 2007 & $\begin{array}{l}\text { SILVA, A. H.; } \\
\text { BADARÓ, A. F. }\end{array}$ & $\begin{array}{l}\text { Influência do alongamento por Facilitação } \\
\text { Neuromuscular Proprioceptiva (FNP) na } \\
\text { flexibilidade de bailarinas }\end{array}$ & $\begin{array}{l}\text { Fisioterapia em } \\
\text { Movimento. (Impresso), } \\
\text { v. } 20 \text {, p. } 109-116,2007 .\end{array}$ \\
\hline
\end{tabular}

Fonte: autora (2020).

Quadro 9 -

Número de artigos publicados em periódicos com o Qualis na área Educação Física ou afim (2008-2018).

\begin{tabular}{|l|c|c|}
\hline \multicolumn{1}{|c|}{ Periódicos } & Número & Qualis $^{7}$ \\
\hline Brasilian Journal Physical Therapy & 1 & A2 \\
\hline Physiotherapy & 1 & A2 \\
\hline Fisioterapia e Pesquisa & 2 & B1 \\
\hline Fisioterapia em Movimento & 2 & B1 \\
\hline Revista CefacC & 1 & B2 \\
\hline Revista Neurociências & 1 & B2 \\
\hline Fisioterapia Brasil & 1 & B2 \\
\hline Revista Terapia Manual & 1 & B3 \\
\hline Saúde (Santa Maria) & 2 & B3 \\
\hline Revista Kairós: Gerontologia & 1 & B4 \\
\hline Revista Eletrônica Gestão e Saúde & 2 & B4* \\
\hline Vittalle & 2 & B4 \\
\hline Cadernos de Educação, Saúde e Fisioterapia & 1 & B5 \\
\hline Fisioterapia Ser & 1 & B5 \\
\hline Convibra Saúde & 2 & 2 \\
\hline
\end{tabular}

${ }^{7}$ Qualis Enfermagem. 


\begin{tabular}{|l|c|c|}
\hline The Fiep Bulletin & 1 & B5 \\
\hline Revista de Educação Física & 1 & B5 \\
\hline Revista Científica do Crefito 05/RS & 1 & - \\
\hline
\end{tabular}

Fonte: autora (2020).

\section{Produção intelectual: capítulo de livro}

No ano de 2013 participei, junto com colegas do departamento de Fisioterapia e Reabilitação, do atendimento às vítimas do incêndio da Boate Kiss, no programa Centro Integrado de Atendimento às Vítimas de Acidentes - Ciava. A reabilitação desses pacientes envolveu docentes do Curso de Fisioterapia, CCS/UFSM, num trabalho voluntário, com os horários agendados para o início da noite durante a semana e aos sábados pela manhã, fora dos atendimentos convencionais do ambulatório do Serviço de Fisioterapia do Husm.

Essa participação resultou na elaboração e na aplicação do protocolo de atendimento, que foi publicado no livro Protocolos de atendimento às vítimas da Boate Kiss, no capítulo Protocolo de atendimento fisioterapêutico, de autoria conjunta com as colegas fisioterapeutas Adriane S. Pasqualoto, Isabela M. de Albuquerque, Ana Lucia C. Prado, Maria Elaine Trevisan, Marisa P. Gonçalves e eu. A primeira edição, volume 1, páginas $135-150$, foi publicada em 2015, versão online e, em 2016, foi lançada a versão impressa, ambas pela editora da UFSM.

\section{Consultor ad hoc de periódicos, editora e agências de fomento}

A realização do doutorado me abriu novos caminhos, para além da pesquisa e do ensino. Com a visibilidade que esse estudo proporcionou, passei a participar como consultor ad hoc de revisões de estudos para periódicos científicos, editora - quadro 10 e agências de fomento à pesquisa - quadro 11.

Essa experiência foi enriquecedora para ampliar meu exercício na análise dos estudos científicos, de modo a me fazer incorporar novos conceitos, outras possibilidades de estudos, linguagens e escrita diversificada. Ao contribuir com esses estudos, considero-me a maior beneficiada.

Tabela 10 -

Revisor de periódicos científicos (2008-2018).

\begin{tabular}{|l|c|c|c|}
\hline \multicolumn{1}{|c|}{ Periódico } & ISSN & Período & Revisões \\
\hline Revista Brasileira de Saúde Ocupacional & $2317-6369$ & 2009 & 01 \\
\hline Revista Brasileira de Fisioterapia & $1809-9246$ & $2009-2013$ & 02 \\
\hline Perspectiva - URI - Erechim & $2178-5937$ & $2012-2014$ & 02 \\
\hline $\begin{array}{l}\text { Revista Brasileira de Saúde Materno- } \\
\text { Infantil }\end{array}$ & $1806-9304$ & 2014 & 01 \\
\hline Trabalho, Educação e Saúde & $1678-1007$ & 2017 & 01 \\
\hline Vitalle (Ufrgs) & $2177-7853$ & 2017 & 01 \\
\hline Edifapes & - & 2017 & 01 \\
\hline Saúde (Santa Maria) & $2236-5834$ & $2011-2018$ & 13 \\
\hline Fisioterapia em Movimento & $1980-5918$ & $2017-2018$ & 04 \\
\hline
\end{tabular}

Fonte: autora (2019). 
Quadro 11 -

Revisor de projeto de agências de fomento.

\begin{tabular}{|c|c|c|c|}
\hline \multicolumn{2}{|l|}{ Fundação } & Período & Revisões \\
\hline $\begin{array}{l}\text { Fundação de Amparo à Pesquisa do } \\
\text { Estado da Bahia }\end{array}$ & Fapesb & $2011-2013$ & 4 \\
\hline $\begin{array}{l}\text { Fundação de Amparo à Ciência e } \\
\text { Tecnologia do Estado de Pernambuco }\end{array}$ & Facepe & $2013-2017$ & 8 \\
\hline
\end{tabular}

Fonte: autora (2019).

\section{Publicação de trabalhos completos, resumos expandidos ou resenhas e resumos na área de ensino, pesquisa e extensão em eventos internacionais e nacionais}

Minhas publicações de trabalhos em eventos tiveram início em 1990, no I Encontro Internacional da Saúde, promovido pelo Centro de Ciências da Saúde da UFSM. Durante esse apresentei os estudos que vinha realizando no Curso de Especialização em Saúde Coletiva: Força de trabalho dos fisioterapeutas de Santa Maria/RS, no ano de 1990 e Força de trabalho dos enfermeiros de Santa Maria/RS, no ano de 1990. Também, nesse evento apresentei o trabalho extensionista que já estava desenvolvendo com os acadêmicos da fisioterapia $A$ questão do lixo na Cidade dos Meninos. No ano de 1992 participei do III Congresso Paulista de Fisioterapia, São Paulo/SP, apresentando meu primeiro resumo de caso clínico, atendido no Serviço de Fisioterapia do Husm intitulado: Desempenho da fisioterapia em um caso de poliomiosite.

Todas essas experiências foram fundamentais para me estimular a relatar nossas vivências, juntamente com os acadêmicos do curso.

No total, foram publicados 115 trabalhos em eventos científicos nacionais e internacionais, no formato de resumo, resumo expandido, completos ou parte de estudos. Desses, 90 foram apresentados no período 2008 a 2018, quadro 12. Após a realização do Doutorado houve maior empenho e dedicação às pesquisas, o que me afastou um pouco da assistência. Isso justifica o crescimento dessa produção.

Apesar de a produção ter sido lenta e progressiva, a participação em eventos da área sempre foi incentivada aos docentes e aos acadêmicos do curso, pois era a forma de eu me atualizar de forma rápida, com o que estava surgindo na fisioterapia, nos grandes centros. Com o início das nossas publicações passamos a participar, mais efetivamente, do cenário nacional da fisioterapia, divulgando meu trabalho e a instituição da qual fazia e faço parte. A participação de alunos em eventos, com apresentação de temas livres e pôsteres, sempre foi muito estimulada pelos professores do curso, e considero que esses eventos são uma oportunidade de os alunos da graduação iniciarem suas publicações.

Na quadro 12, a seguir, apresento o número de trabalhos publicados em anais de eventos nacionais e internacionais no período de 2008 a 2018. 
Quadro 12 -

Trabalhos publicados em anais de eventos nacionais e internacionais (2008-2018).

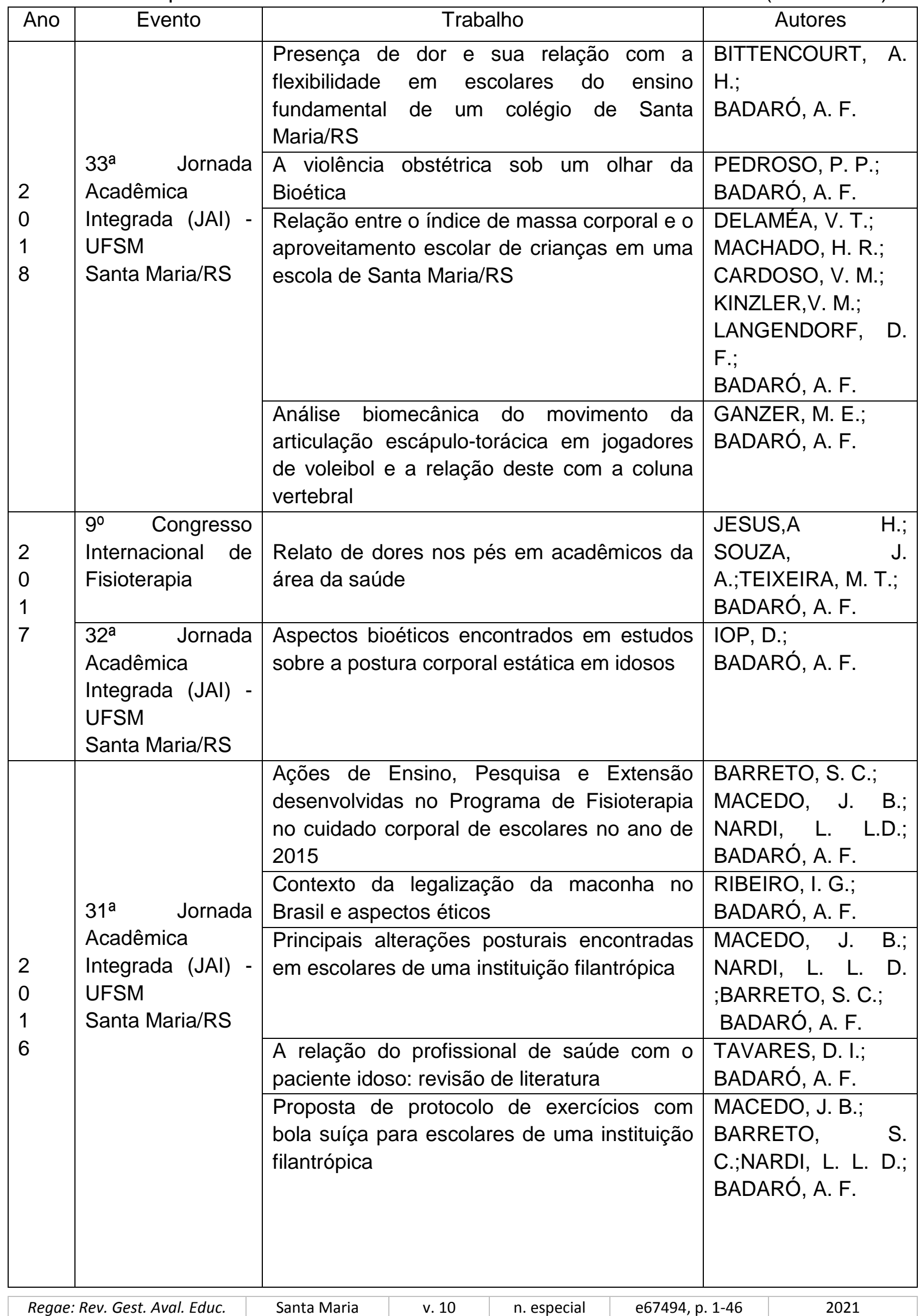




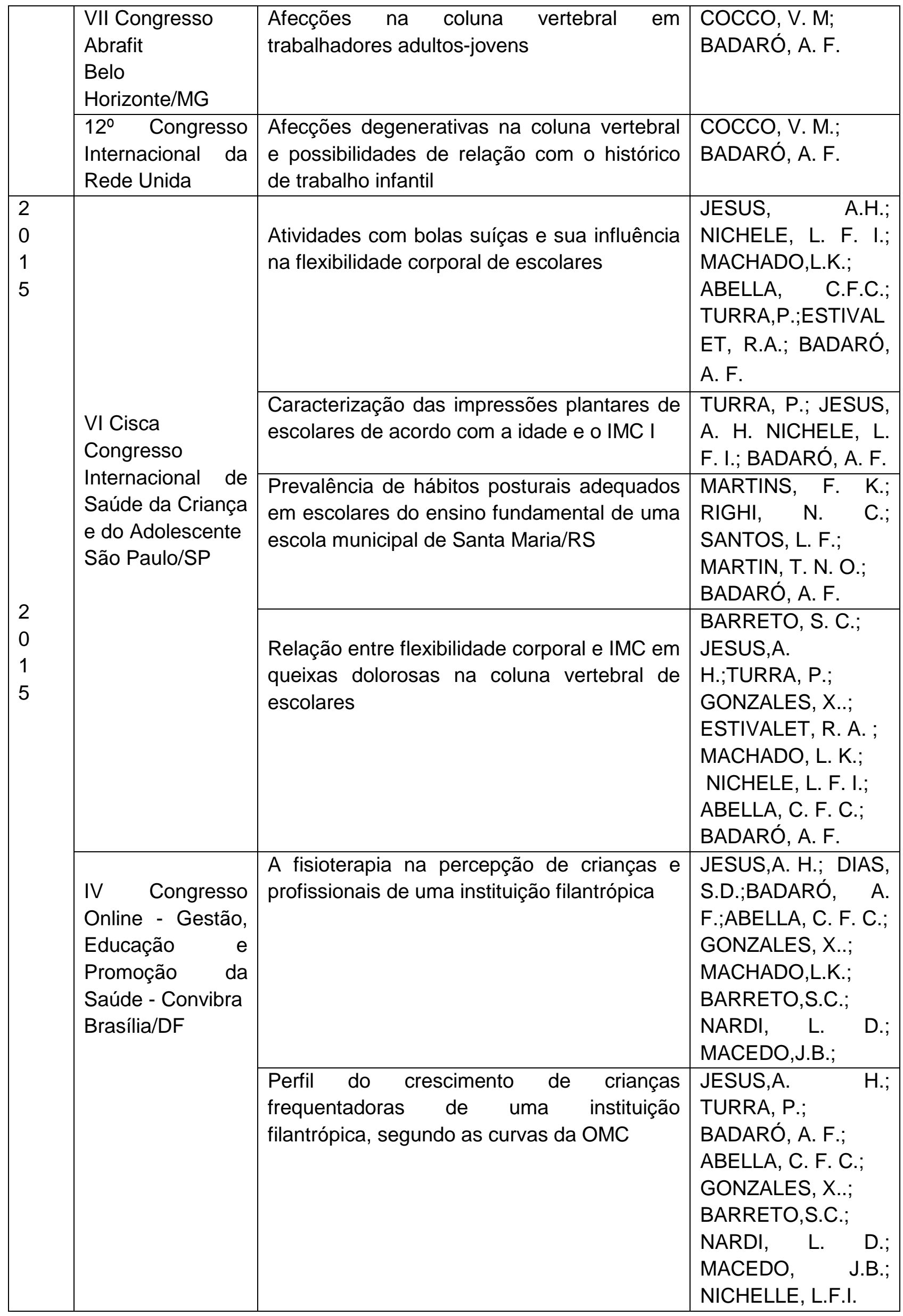




\begin{tabular}{|c|c|c|c|}
\hline & $\begin{array}{l}\text { VI Semana } \\
\text { Científica do } \\
\text { HUSM } \\
\text { Santa Maria/RS }\end{array}$ & $\begin{array}{l}\text { Investigação de dores nos pés de estudantes } \\
\text { do curso de Fisioterapia - UFSM }\end{array}$ & $\begin{array}{l}\text { JESUS, A. H.; } \\
\text { TREVISAN, M. T.; } \\
\text { MARTINS, F. K.; } \\
\text { RIGHI, N. }\end{array}$ \\
\hline & $\begin{array}{l}30^{\mathrm{a}} \quad \text { Jornada } \\
\text { Acadêmica } \\
\text { (JAI) - UFSM, }\end{array}$ & Fisioterapia na escoliose: um estudo de caso & $\begin{array}{l}\text { JACOBSEN, A. A; } \\
\text { MACHADO, R. O; } \\
\text { BADARÓ, A. F. }\end{array}$ \\
\hline & Santa Maria/RS & $\begin{array}{l}\text { Estatura e peso de crianças frequentadoras } \\
\text { do Cefasol quanto as curvas de crescimento } \\
\text { da OMC }\end{array}$ & $\begin{array}{l}\text { BADARÓ, A. F.; } \\
\text { TURRA, P.;ABELLA, } \\
\text { C. F. C.; } \\
\text { NICHELLE, L.F }\end{array}$ \\
\hline \multirow{8}{*}{$\begin{array}{l}2 \\
0 \\
1 \\
4\end{array}$} & $\begin{array}{l}\text { IX Congresso } \\
\text { Brasileiro de } \\
\text { Epidemiologia } \\
\text { Vitória/ES. }\end{array}$ & $\begin{array}{l}\text { Índice de massa corporal e fatores } \\
\text { relacionados em estudantes da rede pública } \\
\text { municipal de Santa Maria/RS }\end{array}$ & $\begin{array}{l}\text { MOURA-SILVA, } \\
\text { M.R.O. G.C.; DALL' } \\
\text { AGNOL, M. M.; } \\
\text { BADARÓ, A. F. }\end{array}$ \\
\hline & $\begin{array}{l}\text { IX Congresso } \\
\text { Brasileiro de } \\
\text { Queimaduras. } \\
\text { Gramado/RS. }\end{array}$ & $\begin{array}{l}\text { Interação entre serviços de Fisioterapia - } \\
\text { HPS/POA e Husm - na reabilitação dos } \\
\text { sobreviventes da Boate Kiss }\end{array}$ & $\begin{array}{l}\text { FERNANDES, } \\
\text { M.; } \\
\text { PRADO, A. L. C.; } \\
\text { TREVISAN, M. E.; } \\
\text { GONÇALVES, M. } \\
\text { P.; } \\
\text { PASQUALOTO, A. } \\
\text { S.; } \\
\text { ALBUQUERQUE, I. } \\
\text { M.; MORAES, J. } \\
\text { P.;BADARÓ, A. F. }\end{array}$ \\
\hline & $\begin{array}{l}6^{\circ} \quad \text { CEBEU } \\
\text { Belém/PA. }\end{array}$ & $\begin{array}{l}\text { Ações extensionistas da fisioterapia com } \\
\text { escolares carentes }\end{array}$ & $\begin{array}{l}\text { NICHELE, L. F.; } \\
\text { TURRA,P.;BADARÓ } \\
\text {, A.F. }\end{array}$ \\
\hline & \multirow{3}{*}{\begin{tabular}{lr} 
IV & \multicolumn{2}{c}{ Congresso } \\
Internacional & de \\
Posturologia & e \\
Fisioterapia & \\
Sorocaba-SP.
\end{tabular}} & $\begin{array}{l}\text { Prevalência de afecções na coluna vertebral } \\
\text { em trabalhadores adultos de um Cerest/RS }\end{array}$ & $\begin{array}{l}\text { BADARÓ, A. F.; } \\
\text { COCCO, V. M.; } \\
\text { JESUS, H. A. }\end{array}$ \\
\hline & & Alterações da postura corporal em crianças & $\begin{array}{l}\text { NICHELE, L. F. I.; } \\
\text { TURRA, P.; } \\
\text { BADARÓ, A. F. }\end{array}$ \\
\hline & & $\begin{array}{l}\text { A influência de um programa de exercícios } \\
\text { com bola suíça sobre a flexibilidade lombar } \\
\text { de escolares }\end{array}$ & $\begin{array}{l}\text { BADARÓ, A. F.; } \\
\text { ZULIAN,T. }\end{array}$ \\
\hline & $\begin{array}{l}32^{\circ} \text { SEURS } \\
\text { Curitiba-PR }\end{array}$ & $\begin{array}{l}\text { Fisioterapia nas ações de saúde com } \\
\text { escolares integradas entre o ensino-pesquisa } \\
\text { e extensão }\end{array}$ & $\begin{array}{l}\text { ABELA,C. F. C.; } \\
\text { MACHADO, L. K.; } \\
\text { BADARÓ, A. F. }\end{array}$ \\
\hline & $\begin{array}{lr}\text { III Congresso } \\
\text { Online - } \\
\text { Educação } \\
\text { Promoção } & \text { da }\end{array}$ & $\begin{array}{l}\text { Avaliação do desenvolvimento motor de } \\
\text { crianças de } 6 \text { a } 9 \text { anos de idade }\end{array}$ & 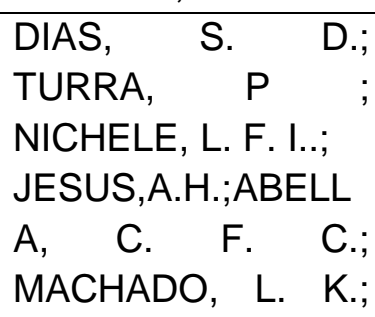 \\
\hline
\end{tabular}




\begin{tabular}{|c|c|c|c|}
\hline & $\begin{array}{l}\text { Saúde, } \\
\text { CONVIBRA }\end{array}$ & & $\begin{array}{l}\text { TREVISAN, } \\
\text { M.;BADARÓ, A. F. }\end{array}$ \\
\hline & Brasília/DF & $\begin{array}{l}\text { Conhecimento de hábitos posturais } \\
\text { verificados em crianças em idade escolar }\end{array}$ & 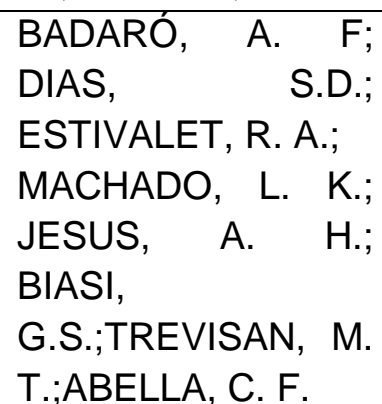 \\
\hline & & $\begin{array}{l}\text { Reflexões éticas e bioéticas apontadas nas } \\
\text { pesquisas com crianças e adolescentes: uma } \\
\text { revisão }\end{array}$ & $\begin{array}{l}\text { BADARÓ, A. F.; } \\
\text { NICHELE, L. F. I.; } \\
\text { TURRA, P.; DIAS, } \\
\text { S. D.; GONZALES, } \\
\text { X.; BARRETO, S. C. }\end{array}$ \\
\hline & & $\begin{array}{lll}\text { Alterações posturais em crianças } & \text { e } \\
\text { adolescentes obesos: revisão de literatura } & \end{array}$ & $\begin{array}{lr}\text { SANTOS, } & \text { E.G.; } \\
\text { SPOHR, } & \text { A.; } \\
\text { MARTINS, } & \text { M.P.; } \\
\text { DIAS, } & \text { S. } \\
\text { D.;BADARÓ, A. F. }\end{array}$ \\
\hline & & $\begin{array}{l}\text { Análise da influência de um programa de } \\
\text { exercícios com bolas suíça na flexibilidade } \\
\text { de escolares de } 11 \text { e } 12 \text { anos }\end{array}$ & $\begin{array}{l}\text { ZULIAN, T.; DIAS, } \\
\text { S. D.; JESUS, A. H.; } \\
\text { BADARÓ, A. F. }\end{array}$ \\
\hline & & $\begin{array}{l}\text { Análise das variações da flexibilidade } \\
\text { corporal por meio do teste de sentar e } \\
\text { alcançar sem banco em escolares, durante } \\
\text { os anos } 2012 \text { e } 2013\end{array}$ & $\begin{array}{l}\text { TURRA, P.; } \\
\text { NICHELE, L. F.; } \\
\text { ZULIAN, T.; } \\
\text { BADARÓ, A. F. }\end{array}$ \\
\hline & $\begin{array}{l}28^{\text {a }} \quad \text { Jornada } \\
\text { Acadêmica } \\
\text { Integrada (JAI) - } \\
\text { UFSM }\end{array}$ & $\begin{array}{l}\text { Apresentação de protocolo de exercícios } \\
\text { para os escolares com uso de bolas suíças - } \\
\text { Fase I }\end{array}$ & $\begin{array}{l}\text { JESUS, A. H.; } \\
\text { ABELLA, C. F. C.; } \\
\text { MACHADO, L. K.; } \\
\text { FELIX, A. B.; } \\
\text { GAZOLA, C.; } \\
\text { BADARÓ, A. F. }\end{array}$ \\
\hline $\begin{array}{l}2 \\
0 \\
1 \\
3\end{array}$ & Santa Maria/RS. & $\begin{array}{l}\text { Apresentação de protocolo de exercícios } \\
\text { para os escolares com uso de bolas suíças - } \\
\text { Fase II }\end{array}$ & $\begin{array}{l}\text { DIAS, S. D.; } \\
\text { BREDOW, D.; } \\
\text { LORENZONI, B. S.; } \\
\text { GARLET, A. B.; } \\
\text { MACHADO, M. T.; } \\
\text { BADARÓ, A. F. }\end{array}$ \\
\hline & & $\begin{array}{l}\text { Visão global das alterações posturais de um } \\
\text { adulto: estudo de caso }\end{array}$ & $\begin{array}{l}\text { HERNANDEZ, } \\
\text { M.; } \\
\text { DELBONI, M. C. C.; } \\
\text { BRAZ, M. M.; } \\
\text { ZULIAN, T.; } \\
\text { MACHADO, M. A.; } \\
\text { BADARÓ, A. F. }\end{array}$ \\
\hline & & $\begin{array}{l}\text { Mensuração do índice de massa corporal de } \\
\text { escolares no município de Santa Maria }\end{array}$ & $\begin{array}{l}\text { KELLING, B. I. ; } \\
\text { STALLBAUM, J. H.; }\end{array}$ \\
\hline
\end{tabular}




\begin{tabular}{|c|c|c|c|}
\hline & & & $\begin{array}{l}\text { ANTUNES, A. G. F.; } \\
\text { SCHILING, E. O.; } \\
\text { FROEMMING, C.; } \\
\text { BADARÓ, A. F. }\end{array}$ \\
\hline & & $\begin{array}{l}\text { Avaliação estática da postura e avaliação da } \\
\text { dor de uma paciente pós-queimaduras }\end{array}$ & $\begin{array}{l}\text { POROLNIK, S.; } \\
\text { PADILHA, J. F.; } \\
\text { DELBONI, M. C. C.; } \\
\text { BRAZ, M. M.; } \\
\text { LEMOS, J. C.; } \\
\text { BADARÓ, A. F. }\end{array}$ \\
\hline & & $\begin{array}{l}\text { Comparação entre os sexos das categorias } \\
\text { de movimentos fundamentais proposta } \\
\text { Gallahue }\end{array}$ & $\begin{array}{l}\text { TREVISAN, C. M.; } \\
\text { JESUS, } \\
\text { H.;NICHELE, L. F. I.; } \\
\text { TURRA, P.; DIAS, } \\
\text { S. D.MACHADO, L. } \\
\text { K.; } \\
\text { LORENZONI, B. S.; } \\
\text { MACHADO, M. T.; } \\
\text { BADARÓ, A. F. }\end{array}$ \\
\hline 2013 & $\begin{array}{l}\text { V Congresso } \\
\text { Internacional de } \\
\text { Saúde da Criança }\end{array}$ & $\begin{array}{l}\text { Perfil dos estudos sobre avaliação da postura } \\
\text { corporal em escolares: duas décadas de } \\
\text { pesquisas brasileiras }\end{array}$ & $\begin{array}{l}\text { MARQUES, T. D.; } \\
\text { TURRA, P.; } \\
\text { NICHELE, L. F. I.; } \\
\text { BADARÓ, A. F. }\end{array}$ \\
\hline & $\begin{array}{l}\text { e do Adolescente } \\
\text { Journal of Human } \\
\text { Growth and } \\
\text { Development, } \\
\text { São Caetano do } \\
\text { Sul/SP }\end{array}$ & $\begin{array}{l}\text { Relação do índice de massa corporal (IMC) } \\
\text { com valgismo de joelho em escolares }\end{array}$ & $\begin{array}{l}\text { NICHELE, } \\
\text { TURRA, } \\
\text { BREDOW, D.; } \\
\text { GAZOLA, C.; FELIX, } \\
\text { A. B.; BADARÓ, A. } \\
\text { F. }\end{array}$ \\
\hline & & $\begin{array}{l}\text { Influência de um programa de exercícios com } \\
\text { bola suíça em escolares de } 7 \text { a } 12 \text { anos com } \\
\text { queixas dolorosas }\end{array}$ & 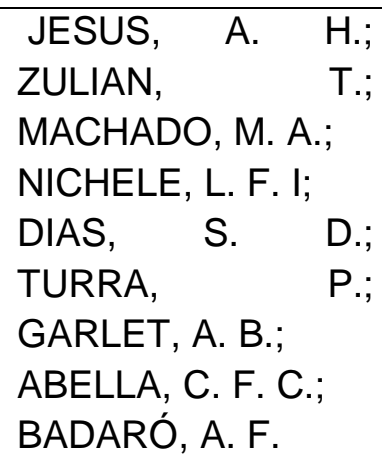 \\
\hline & $\begin{array}{lr}\text { XXIII } & \text { Fórum } \\
\text { Nacional } & \text { de } \\
\text { Ensino } & \text { em } \\
\text { Fisioterapia } & \\
\text { Abenfisio, } & \\
\text { Curitiba/PR. } & \end{array}$ & $\begin{array}{l}\text { Ensino da ética profissional e da bioética na } \\
\text { formação dos fisioterapeutas e terapeutas } \\
\text { ocupacionais do Rio Grande do Sul }\end{array}$ & $\begin{array}{lcc}\text { FLEIG, } & \text { T. } & \text { C.; } \\
\text { FELIX, } & \text { M. } & \text { A.; } \\
\text { MELO, } & \text { D.A. } & \text { S.; } \\
\text { GLOCK, } & \text { R.; } \\
\text { SILVA,C.S.;SOARE } \\
\text { S, A.;BADARÓ, A. } \\
\text { F. } \\
\text { WERTHEIMER,L. } \\
\text { C.; } \\
\text { FINGER, A. V.; }\end{array}$ \\
\hline
\end{tabular}




\begin{tabular}{|c|c|c|c|}
\hline & & $\begin{array}{l}\text { Tratamento cinesioterapêutico da escoliose } \\
\text { idiopática do adolescente: estudo de revisão }\end{array}$ & $\begin{array}{l}\text { ARAUJO, M.; } \\
\text { BADARÓ, A. F. }\end{array}$ \\
\hline & $\begin{array}{lr}\text { X Congresso } \\
\text { Brasileiro de } \\
\text { Bioética e } \\
\text { Congresso }\end{array}$ & $\begin{array}{l}\text { Ética e bioética na formação dos } \\
\text { fisioterapeutas do RS }\end{array}$ & $\begin{array}{l}\text { FLEIG, T. C.; FELIX, } \\
\text { M. A.; FINGER, A. } \\
\text { V.;MELO, D. A. S.; } \\
\text { CAMERA,F.;GLOCK } \\
\text {, R.; BADARÓ, A.F. }\end{array}$ \\
\hline & $\begin{array}{l}\text { Brasileiro de } \\
\text { Bioética Clínica, } \\
\text { Florianópolis/SC }\end{array}$ & $\begin{array}{l}\text { O ensino da bioética no curso de } \\
\text { Especialização em Reabilitação Físico- } \\
\text { Motora - UFSM }\end{array}$ & $\begin{array}{l}\text { DELBONI, M. C. C.; } \\
\text { BADARÓ, A. F. }\end{array}$ \\
\hline & $\begin{array}{l}\text { VII Congresso } \\
\text { Sul Brasileiro de } \\
\text { Fisioterapia } \\
\text { Cardiorrespiratóri } \\
\text { a e Fisioterapia } \\
\text { em TI } \\
\text { - Sulbrafir - Porto } \\
\text { Alegre-RS }\end{array}$ & $\begin{array}{l}\text { Prevalência de sinais e sintomas da } \\
\text { intoxicação por cianeto nos sobreviventes do } \\
\text { incêndio na boate Kiss, Santa Maria, RS, } \\
\text { Brasil: resultados preliminares }\end{array}$ & $\begin{array}{l}\text { GONÇALVES, } \\
\text { P.; } \\
\text { PASQUALOTO, } \\
\text { S.; } \\
\text { ALBUQUERQUE, I. } \\
\text { M.; TREVISAN, M. } \\
\text { E.; PRADO, A. L. C.; } \\
\text { MORAES, J. P.; } \\
\text { BADARÓ, A. F. }\end{array}$ \\
\hline & $\begin{array}{l}\text { IV Congresso } \\
\text { Internacional de } \\
\text { Saúde da Criança } \\
\text { e do Adolescente, }\end{array}$ & $\begin{array}{l}\text { Ações Interdisciplinares para } \\
\text { acompanhamento do desenvolvimento de } \\
\text { crianças da terceira infância }\end{array}$ & $\begin{array}{ll}\text { FERNANDES, D. L.; } \\
\text { TREVISAN, C .; } \\
\text { NEDEL, S. } & \text { S.; } \\
\text { ZULIAN, } & \text { T.; } \\
\text { NICHELE, L. } & \text { F. } \\
\text { I..;TURRA, P.; } & \\
\text { BADARÓ, A. F. } & \end{array}$ \\
\hline & & $\begin{array}{l}\text { Análise do desenvolvimento motor em } \\
\text { escolares de } 6 \text { a } 9 \text { anos de idade }\end{array}$ & $\begin{array}{l}\text { TURRA, } \\
\text { NICHELE, L. F. I.; } \\
\text { TREVISAN, C. M..; } \\
\text { BASSO, D. B. A.; } \\
\text { NASCIMENTO, J. } \\
\text { R.;SCHIMIDT, F. C.; } \\
\text { POZZEBON, N. M.; } \\
\text { BADARÓ, A. F. }\end{array}$ \\
\hline & & $\begin{array}{l}\text { Relação entre o teste de sentar - alcançar } \\
\text { adaptado e o índice de Schöber aplicados a } \\
\text { escolares de } 7 \text { a } 12 \text { anos }\end{array}$ & $\begin{array}{l}\text { NICHELE, L. F.; } \\
\text { TURRA, } \\
\text { FERNANDES, D. L.; } \\
\text { BASSO, D. B. A.; } \\
\text { CABELEIRA, } \\
\text { M.;REAL, } \\
\text { BADARÓ, A. F. }\end{array}$ \\
\hline & $\begin{array}{l}\text { Mercomovimento } \\
\text { Santa Maria/RS }\end{array}$ & $\begin{array}{l}\text { Epidemiologia da dor lombar não específica } \\
\text { em crianças e adolescentes }\end{array}$ & $\begin{array}{l}\text { MOURA-SILVA, } \\
\text { R. O. G. G. } \\
\text { BADARÓ, A. F. }\end{array}$ \\
\hline & $\begin{array}{l}2^{a} \text { Mostra de } \\
\text { Banners do CCS } \\
\text { Santa Maria/RS }\end{array}$ & $\begin{array}{l}\text { Análise do desenvolvimento motor em } \\
\text { escolares de } 6 \text { a } 9 \text { anos de idade }\end{array}$ & $\begin{array}{l}\text { TURRA, } \\
\text { NICHELE, L. F. I.; } \\
\text { TREVISAN, C. M. ; } \\
\text { PIVETTA, H. M. F.; }\end{array}$ \\
\hline
\end{tabular}




\begin{tabular}{|c|c|c|}
\hline & & $\begin{array}{l}\text { NASCIMENTO, J. } \\
\text { R.; SCHIMIDT, F. } \\
\text { C.; } \\
\text { POZZEBON, N. M.; } \\
\text { BADARÓ, A. F. }\end{array}$ \\
\hline & $\begin{array}{l}\text { Avaliação estática da posição escapular de } \\
\text { pacientes em pré-operatório do manguito } \\
\text { rotador }\end{array}$ & $\begin{array}{l}\text { ZIMMER, V.; } \\
\text { BADARÓ, A. F. }\end{array}$ \\
\hline \multirow[t]{2}{*}{$\begin{array}{l}8^{0} \quad \text { Congresso } \\
\text { Internacional de } \\
\text { Bioética Clínica } \\
\text { São Paulo/SP }\end{array}$} & $\begin{array}{l}\text { Reflexões bioéticas sobre envolvimento } \\
\text { amoroso nas relações terapeuta-paciente }\end{array}$ & $\begin{array}{l}\text { DELBONI, C. C.; } \\
\text { ARRUDA, A. P.; } \\
\text { SERAFIM, S. D.; } \\
\text { BADARÓ, A. F. }\end{array}$ \\
\hline & $\begin{array}{l}\text { Autonomia profissional e autonomia do } \\
\text { paciente: relato de casos na fisioterapia }\end{array}$ & $\begin{array}{l}\text { DELBONI, C. C.;; } \\
\text { BADARÓ, A. F.; } \\
\text { SILVA, M. M.; } \\
\text { MEEREIS, E. C.W.; } \\
\text { ZIMMER,V. }\end{array}$ \\
\hline $\begin{array}{l}\text { VI Ccongresso } \\
\text { Internacional de } \\
\text { Fisioterapia }\end{array}$ & $\begin{array}{l}\text { Análise e correlações das curvaturas da } \\
\text { coluna vertebral e do alinhamento pélvico em } \\
\text { mulheres com diferentes faixas etárias }\end{array}$ & $\begin{array}{l}\text { WEBER, L.M. } \\
\text { BADARÓ, A. F. }\end{array}$ \\
\hline \multirow{3}{*}{$\begin{array}{lr}\text { XXII } & \text { Fórum } \\
\text { Nacional } & \text { de } \\
\text { Ensino } & \text { em } \\
\text { Fisioterapia } & \text { da } \\
\text { Abenfisio } \\
\text { III Congresso } \\
\text { Nacional de } \\
\text { Fisioterapia na } \\
\text { Saúde Coletiva } \\
\text { - } \\
\text { Brasília/DF }\end{array}$} & $\begin{array}{lrrr}\begin{array}{l}\text { Metodologia } \\
\text { experiência }\end{array} & \text { na } & \text { Ensino Superior: } & \text { uma } \\
\text { fisioterapia. } & & & \\
\end{array}$ & $\begin{array}{l}\text { PIVETTA, H. M. F.; } \\
\text { VOGT, M. S. L; } \\
\text { BADARÓ, A. F. }\end{array}$ \\
\hline & $\begin{array}{l}\text { Avaliação como Metodologia Ativa de Ensino } \\
\text { Aprendizagem em Fisioterapia }\end{array}$ & $\begin{array}{l}\text { PIVETTA, H. M. F.; } \\
\text { BADARÓ, A. F.; } \\
\text { VOGT, M. S. L. }\end{array}$ \\
\hline & $\begin{array}{l}\text { Docência orientada: uma vivencia de ensino- } \\
\text { aprendizagem em fisioterapia }\end{array}$ & $\begin{array}{l}\text { PIVETTA, H. M. F.; } \\
\text { BADARÓ, A. F.; } \\
\text { VOGT, M. S. L. }\end{array}$ \\
\hline \multirow{6}{*}{$\begin{array}{l}27^{a} \text { Jornada } \\
\text { Acadêmica } \\
\text { Integrada - JAI } \\
27^{\circ} \text { Salão de } \\
\text { Iniciação } \\
\text { Científica, } \\
\text { Santa Maria/RS }\end{array}$} & $\begin{array}{l}\text { Alterações da biomecânica da coluna } \\
\text { vertebral durante a gestação e a importância } \\
\text { da atuação fisioterapêutica }\end{array}$ & $\begin{array}{l}\text { FREIRE, A. B.; } \\
\text { BADARÓ, A. F. }\end{array}$ \\
\hline & $\begin{array}{l}\text { Ação do músculo psoas na pelve e sua } \\
\text { influência na postura corporal }\end{array}$ & $\begin{array}{l}\text { LOPES, I. M.; } \\
\text { BADARÓ, A. F. }\end{array}$ \\
\hline & $\begin{array}{l}\text { Avaliação do alinhamento da postura } \\
\text { corporal, em perfil, de crianças em idade } \\
\text { escolar }\end{array}$ & $\begin{array}{l}\text { FERNANDES, D. L.; } \\
\text { BADARÓ, A. F. }\end{array}$ \\
\hline & $\begin{array}{l}\text { Identificação de alterações nos Joelhos e sua } \\
\text { relação com os pés em crianças em idade } \\
\text { escolar }\end{array}$ & $\begin{array}{l}\text { CABELEIRA, M. E. } \\
\text { P.; MURARO, M. F. } \\
\text { R.; BADARÓ, A. F. }\end{array}$ \\
\hline & $\begin{array}{l}\text { Avaliações e acompanhamento do } \\
\text { crescimento e do desenvolvimento corporal } \\
\text { de escolares }\end{array}$ & $\begin{array}{l}\text { NICHELE, L. F. I.; } \\
\text { TURRA, P.; } \\
\text { BADARÓ, A. F. }\end{array}$ \\
\hline & $\begin{array}{l}\text { Verificação de queixas dolorosas em } \\
\text { crianças de } 6 \text { a } 12 \text { anos, frequentadoras de } \\
\text { uma instituição de apoio socioeducativo }\end{array}$ & $\begin{array}{l}\text { REAL, A.A; } \\
\text { BADARÓ, A. F. }\end{array}$ \\
\hline
\end{tabular}




\begin{tabular}{|c|c|c|c|}
\hline & & $\begin{array}{l}\text { Verificação da influência dos arcos plantares } \\
\text { em possíveis alterações posturais, segundo } \\
\text { a literatura atual }\end{array}$ & $\begin{array}{l}\text { STALLBAUM, J. H.; } \\
\text { BADARÓ, A. F. }\end{array}$ \\
\hline & & $\begin{array}{l}\text { Síndrome do respirador oral e } \\
\text { influências na postura corporal }\end{array}$ & $\begin{array}{l}\text { POZZEBON, N. M.; } \\
\text { BREAL, A. A.; } \\
\text { CABELEIRA, M. E. } \\
\text { P.;NARDI, A. T.; } \\
\text { BADARÓ, A. F. }\end{array}$ \\
\hline & $\begin{array}{l}\text { XIX Congresso } \\
\text { Brasileiro de }\end{array}$ & $\begin{array}{l}\text { Concepções de fisioterapeutas sobre a cura } \\
\text { no processo saúde-doenca }\end{array}$ & $\begin{array}{l}\text { GUILHEM, D.; } \\
\text { BADARÓ A.F }\end{array}$ \\
\hline & $\begin{array}{l}\text { Fisioterapia, } \\
\text { Florianópolis/SC }\end{array}$ & $\begin{array}{l}\text { Estudo retrospectivo, em imagens } \\
\text { radiográficas, das curvaturas da coluna } \\
\text { vertebral e da posição pélvica }\end{array}$ & $\begin{array}{l}\text { HAHN, P. T.; } \\
\text { ULGUIM, C.; } \\
\text { BADARÓ, A. F. }\end{array}$ \\
\hline $\begin{array}{l}2 \\
0 \\
1 \\
1\end{array}$ & $\begin{array}{l}\text { XI Congresso } \\
\text { Iberoamericano } \\
\text { de Extension } \\
\text { Universitária } \\
\text { Santa Fé- } \\
\text { Argentina }\end{array}$ & $\begin{array}{l}\text { Fisioterapia na saúde do escolar: uma } \\
\text { vivência de ensino }\end{array}$ & $\begin{array}{l}\text { HAUCK, } \\
\text { MIOZZO, A. } \\
\text { SIMOES, G. D..; } \\
\text { TEIXEIRA, M. C.; } \\
\text { BADARÓ, A. F. }\end{array}$ \\
\hline & $\begin{array}{l}\text { III Congresso } \\
\text { Internacional de } \\
\text { Saúde da Criança } \\
\text { e do Adolescente }\end{array}$ & $\begin{array}{l}\text { Atividades de relaxamento e alongamento, } \\
\text { com bolas suíças com crianças carentes }\end{array}$ & $\begin{array}{l}\text { MARQUES, T. D.; } \\
\text { GRANDO, A. C.; } \\
\text { BADARÓ, A. F. }\end{array}$ \\
\hline & $\begin{array}{l}\text { IIV Encontro } \\
\text { Brasileiro de } \\
\text { Motricidade }\end{array}$ & $\begin{array}{l}\text { As funções estomatognáticas e a postura } \\
\text { corporal nos respiradores orais obstrutivos e } \\
\text { funcionais }\end{array}$ & $\begin{array}{l}\text { MACHADO, P. G.; } \\
\text { MEZZOMO, C. L.; } \\
\text { BERWIG, L. C.; } \\
\text { BADARÓ, A. F. }\end{array}$ \\
\hline & $\begin{array}{l}\text { Orofacial } \\
\text { Natal/RN }\end{array}$ & $\begin{array}{l}\text { A relação entre a postura corporal e as } \\
\text { funções estomatognáticas em respiradores } \\
\text { orais }\end{array}$ & $\begin{array}{l}\text { MACHADO, P. G.; } \\
\text { MEZZOMO, C. L.; } \\
\text { COSTA, P. P.; } \\
\text { BADARÓ, A. F. }\end{array}$ \\
\hline & $\begin{array}{lr}\text { XXI } & \text { Fórum } \\
\text { Nacional } & \text { de } \\
\text { Ensino } & \text { em } \\
\text { Fisioterapia } & \end{array}$ & $\begin{array}{l}\text { Saúde do escolar: um exemplo de } \\
\text { transversalidade no ensino da Fisioterapia }\end{array}$ & BADARÓ, A. F. \\
\hline & $\begin{array}{l}\text { Congresso } \\
\text { Internacional de } \\
\text { Fisioterapia, Ética } \\
\text { e Bioética } \\
\text { Vitória/ES }\end{array}$ & $\begin{array}{l}\text { Autonomia profissional dos fisioterapeutas; } \\
\text { limites e implicações }\end{array}$ & $\begin{array}{l}\text { BADARÓ, A. F. } \\
\text { GUILHEM,D. }\end{array}$ \\
\hline & $\begin{array}{l}5^{\circ} \text { Congresso } \\
\text { Brasileiro de } \\
\text { Extensão } \\
\text { Universitária: } \\
\text { as fronteiras da } \\
\text { extensão. } \\
\text { Porto Alegre/RS }\end{array}$ & $\begin{array}{l}\text { Ações fisioterapêuticas, de extensão e } \\
\text { pesquisa, na saúde do escolar }\end{array}$ & $\begin{array}{l}\text { MARQUES, T. D.; } \\
\text { MACHADO, P. G.; } \\
\text { RITTER, A. L.; } \\
\text { GRANDO, A. C.; } \\
\text { BASSO, D. B. A.; } \\
\text { BADARÓ, A. F. }\end{array}$ \\
\hline
\end{tabular}




\begin{tabular}{|c|c|c|c|}
\hline \multirow{5}{*}{$\begin{array}{l}2 \\
0 \\
1 \\
0\end{array}$} & \multirow{4}{*}{$\begin{array}{l}25^{\mathrm{a}} \quad \text { Jornada } \\
\text { Acadêmica } \\
\text { Integrada - JAI } \\
\text { Santa Maria/RS }\end{array}$} & Ações da fisioterapia na saúde do escolar & $\begin{array}{l}\text { SILVEIRA, F. P.; } \\
\text { BORBA, M. M.; } \\
\text { BADARÓ, A. F.; } \\
\text { SIMOES,G.D.;RITT } \\
\text { ER,A. L.; }\end{array}$ \\
\hline & & $\begin{array}{l}\text { Adoção de posturas adequadas na posição } \\
\text { deitada: uma orientação fisioterapêutica }\end{array}$ & $\begin{array}{l}\text { MONTAGNER, J. F.; } \\
\text { BADARÓ, A. F.; } \\
\text { SIMOES, G. D. }\end{array}$ \\
\hline & & $\begin{array}{l}\text { Alterações posturais em escolares do ensino } \\
\text { fundamental de uma escola pública de Santa } \\
\text { Maria/RS }\end{array}$ & $\begin{array}{l}\text { CORDEIRO, J. L.; } \\
\text { CASTILLO, B. L. D.; } \\
\text { PIGATTO, G. R.; } \\
\text { MIOZZO, A. } \\
\text { PLACK, } \\
\text { BADARÓ, A. F. }\end{array}$ \\
\hline & & $\begin{array}{l}\text { Avaliação da dor em crianças de } 4^{\text {a }} \text { série do } \\
\text { ensino fundamental de uma escola da rede } \\
\text { pública }\end{array}$ & $\begin{array}{l}\text { SIMOES, G. D.; } \\
\text { BADARÓ, A. F.; } \\
\text { RECK, L.; BRASIL, } \\
\text { M. P.;SANTOS, } \\
\text { E.;MOZZO,A. P. }\end{array}$ \\
\hline & \multirow{5}{*}{$\begin{array}{l}25^{\mathrm{a}} \quad \text { Jornada } \\
\text { Acadêmica } \\
\text { Integrada - JAI } \\
\text { Santa Maria/RS }\end{array}$} & $\begin{array}{l}\text { Avaliação de carga escolar, modelo de } \\
\text { transporte de mochila em estudantes da } 4^{\underline{a}} \\
\text { série do ensino fundamental }\end{array}$ & $\begin{array}{l}\text { HAUCK, M.; RECK, } \\
\text { L.; MONTAGNER, J. } \\
\text { F.;PIGATTO, G. R; } \\
\text { BADARÓ, A. F. }\end{array}$ \\
\hline \multirow{5}{*}{$\begin{array}{l}201 \\
0\end{array}$} & & $\begin{array}{l}\text { Avaliação postural por fotogrametria em } \\
\text { crianças de } 6 \text { a } 8 \text { anos }\end{array}$ & $\begin{array}{l}\text { BADARÓ, A. F.; } \\
\text { RITTER, A. } \\
\text { BASSO, } \quad \text { D. } \\
\text { GUEDES, C. O.; } \\
\text { SILVEIRA, F. P.; } \\
\text { BORBA, M. M. }\end{array}$ \\
\hline & & $\begin{array}{l}\text { Fisioterapia na educação em saúde de } \\
\text { escolares do ensino fundamental }\end{array}$ & $\begin{array}{l}\text { RECK, L.; RITTER, } \\
\text { A. L.;BADARÓ, A. } \\
\text { F.;BRASIL, M. P.; } \\
\text { SIMÕES, G. D.; } \\
\text { MONTAGNER, J. F. }\end{array}$ \\
\hline & & $\begin{array}{l}\text { Relação entre desvios posturais e carga de } \\
\text { mochila escolar em estudantes da } 4^{a} \text { série do } \\
\text { ensino fundamental. }\end{array}$ & $\begin{array}{l}\text { HAUCK, M.; PLACK, } \\
\text { F.;BADARÓ, A. F.; } \\
\text { SANTOS, E.; } \\
\text { MONTAGNER, J. F.; }\end{array}$ \\
\hline & & $\begin{array}{l}\text { Um estudo sobre o uso de coxins para o } \\
\text { posicionamento ideal em diferentes } \\
\text { decúbitos }\end{array}$ & $\begin{array}{l}\text { HAUCK, M.; } \\
\text { CORDEIRO, J. L.; } \\
\text { CASTILLO, B. L. D.; } \\
\text { SANTOS, } \\
\text { MOZZO, } \\
\text { BADARÓ, A. F. }\end{array}$ \\
\hline & $\begin{array}{l}\text { II Congresso } \\
\text { Internacional de } \\
\text { Saúde da Criança } \\
\text { e do Adolescente, }\end{array}$ & Ações fisioterapêuticas na saúde do escolar & $\begin{array}{l}\text { SILVEIRA, F. P.; } \\
\text { BORBA, M. M.; } \\
\text { RECK, L.;BADARÓ, } \\
\text { A. F. }\end{array}$ \\
\hline
\end{tabular}




\begin{tabular}{|c|c|c|c|}
\hline & São Paulo/SP & & $\begin{array}{lll}\text {;SIMÕES, G. } & \text { D.; } \\
\text { BASSO, } & & \text { D.; } \\
\text { BRASIL, M. } & \text { P.; } \\
\text { GUEDES, } & \text { C. } \\
\text { O.;MONTAGNER, J. } \\
\text { F.; }\end{array}$ \\
\hline & $\begin{array}{l}9^{\circ} \quad \text { Congresso } \\
\text { Nacional da Rede } \\
\text { Unida, } \\
\text { Porto Alegre/RS }\end{array}$ & $\begin{array}{l}\text { A fisioterapia na saúde do escolar: uma } \\
\text { experiência de ensino-assistência }\end{array}$ & $\begin{array}{l}\text { BADARÓ, A. F.; } \\
\text { COSTA,GM.;SILVEI } \\
\text { R, PF.RITTER,A.L.; } \\
\text { HAHN,PT;BASSO,D } \\
\text {; ULGUIM,CB; } \\
\text { MARTINI,AP; } \\
\text { CAMPONOGARA,S } \\
\text { F. }\end{array}$ \\
\hline & & $\begin{array}{l}\text { Os limites ao pleno exercício da autonomia } \\
\text { profissional dos fisioterapeutas: implicações } \\
\text { na qualidade assistencial }\end{array}$ & $\begin{array}{l}\text { BADARÓ, A. F.; } \\
\text { GUILHEM, D. }\end{array}$ \\
\hline & & $\begin{array}{l}\text { Saúde do escolar, a fisioterapia e a equipe } \\
\text { multidisciplinar: qual a realidade? Atenção } \\
\text { integrada ou campo experimental? }\end{array}$ & BADARÓ, A. F. \\
\hline $\begin{array}{l}2 \\
0 \\
0\end{array}$ & \begin{tabular}{lr}
\multicolumn{1}{c}{ Simpósio } & de \\
Atenção & \\
Multidisciplinar da \\
Saúde & do \\
Adolescente & \\
São Paulo/SP &
\end{tabular} & $\begin{array}{l}\text { Atenção fisioterapêutica na saúde dos } \\
\text { escolares In: I Simpósio de Atenção } \\
\text { Multidisciplinar da Saúde do Adolescente }\end{array}$ & $\begin{array}{l}\text { COSTA,G.M.;GUED } \\
\text { ES,C.O.;POLACHIN } \\
\text { C. R.;TREVISAN, } \\
\text { C. M.; BASSO, D.; } \\
\text { BADARÓ, A.F. }\end{array}$ \\
\hline 9 & $\begin{array}{l}\text { Congrega } \\
\text { URCAMP } \\
\text { Bagé/RS }\end{array}$ & $\begin{array}{l}\text { Cuidando da postura de escolares por meio } \\
\text { de avaliação fotogramétrica e atividades } \\
\text { físico-motora }\end{array}$ & $\begin{array}{ll}\text { BASSO, D.; COSTA, } \\
\text { G. M.; GUEDES, C. } \\
\text { O.;POLACHINI, C. } \\
\text { R.;TREVISAN, C. } \\
\text { M.; } \\
\text { BADARÓ, A. F. }\end{array}$ \\
\hline & $\begin{array}{ll}\text { Simpósio } & \text { de } \\
\text { Adolescência } & \text { do } \\
\text { CAAA } & \\
\text { São Paulo/SP } & \end{array}$ & $\begin{array}{l}\text { Fisioterapia no acompanhamento do } \\
\text { crescimento e do desenvolvimento corporal } \\
\text { de escolares }\end{array}$ & $\begin{array}{ll}\text { GUEDES, C. } & \text { O.; } \\
\text { COSTA, G. } & \text { M.; } \\
\text { TREVISAN, C. } & \text { M.; } \\
\text { POLACHINI, C. R.; } \\
\text { BASSO, } \\
\text { BADARÓ, A.F. }\end{array}$ \\
\hline & $\begin{array}{l}2^{\circ} \quad \text { Fórum } \\
\text { Extensão } \\
\text { Santa Maria/RS }\end{array}$ & $\begin{array}{llll}\text { Fisioterapia } & \text { no } & \text { acompanhamento } & \text { do } \\
\text { crescimento } & \text { e do desenvolvimento } & \text { de } \\
\text { escolares } & & & \end{array}$ & $\begin{array}{lrr}\text { COSTA, G. } & \text { M.; } \\
\text { GUEDES, } & \text { C. } & \text { O.; } \\
\text { BADARÓ, A. F. } & \end{array}$ \\
\hline & $\begin{array}{l}\text { II Congresso } \\
\text { Internacional de } \\
\text { Reabi-litação } \\
\text { Neuro-músculo } \\
\text { esquelética e } \\
\text { Esportiva, Belo } \\
\text { Horizonte/MG }\end{array}$ & $\begin{array}{l}\text { Importância das fáscias nas abordagens } \\
\text { fisioterapêuticas da cadeia respiratória }\end{array}$ & $\begin{array}{l}\text { ROHDE, O. E.; } \\
\text { TREVISAN, M. E.; } \\
\text { BADARÓ, A. F. }\end{array}$ \\
\hline
\end{tabular}




\begin{tabular}{|c|c|c|c|}
\hline $\begin{array}{l}2 \\
0\end{array}$ & $\begin{array}{l}\text { Congresso } \\
\text { Mundial }\end{array}$ & $\begin{array}{l}\text { Fisioterapeutas de Santa Maria/RS: perfil } \\
\text { profissional, áreas de atuação e população } \\
\text { assistida }\end{array}$ & $\begin{array}{l}\text { GUILHEM, D.; } \\
\text { BADARÓ, A. F. }\end{array}$ \\
\hline $\begin{array}{l}0 \\
8\end{array}$ & $\begin{array}{l}\text { Epidemiologia, } \\
\text { Porto Alegre/RS }\end{array}$ & $\begin{array}{l}\text { Um olhar da fisioterapia junto aos } \\
\text { trabalhadores de saúde da família }\end{array}$ & $\begin{array}{l}\text { VOGT, M. S. L.; } \\
\text { BADARÓ, A. F. }\end{array}$ \\
\hline
\end{tabular}

\section{Premiações científicas na área de ensino, pesquisa e extensão relacionadas a atividades-fim}

Em 1994 tivemos o primeiro trabalho científico, do Curso de Fisioterapia da UFSM, premiado num evento. Os estudos realizados pelas acadêmicas Carla Arend e Silvana Magalhães, em orientação conjunta com a profa Maria Elaine Trevisan, foram apresentados no VII Simpósio Internacional de Fisioterapia Respiratória, em Salvador/BA, recebendo o Prêmio Acadêmico Prof. Celso Figueiroa, $1^{\circ}$ lugar. Essa premiação foi uma grande surpresa para nós, jamais imaginávamos alcançar destaque nacional. Esse prêmio, além de divulgar nosso trabalho e nossa instituição, demonstrou, para a comunidade acadêmica da fisioterapia, que estávamos no caminho certo, algo do que nos orgulhamos muito.

Nos anos seguintes outros colegas do nosso Departamento também tiveram seus trabalhos reconhecidos. Tempos depois obtivemos mais quatro reconhecimentos em trabalhos apresentados em eventos científicos, que vieram a corroborar nossos esforços na área da pesquisa em Fisioterapia e saúde, os quais estão listados no quadro 13.

Quadro 13 -

Trabalhos acadêmicos premiados.

\begin{tabular}{|c|c|c|c|}
\hline Ano e evento & Trabalho & Prêmio & Autores \\
\hline $\begin{array}{l}\text { I Congresso Virtual } \\
\text { Brasileiro Gestão, } \\
\text { Educação } \\
\text { Promoção da Saúde }\end{array}$ & $\begin{array}{l}\text { Apresentação de um } \\
\text { programa de fisioterapia } \\
\text { no cuidado corporal de } \\
\text { escolares }\end{array}$ & $\begin{array}{l}\text { Prêmio CONVIBRA } \\
\text { "Melhores Artigos" }\end{array}$ & $\begin{array}{l}\text { NICHELE, L. F. I.; } \\
\text { FERNANDES, D. L.; } \\
\text { ZULIAN,T.; TURRA, } \\
\text { P.; } \\
\text { BASSO, D. B. A.; } \\
\text { BADARÓ, A. F. }\end{array}$ \\
\hline $\begin{array}{ll}2013 & \\
\text { V Congresso } \\
\text { Internacional da } \\
\text { Criança e do } \\
\text { Adolescente } \\
\text { V CISCA } \\
\text { São Caetano do } \\
\text { Sul/SP }\end{array}$ & $\begin{array}{l}\text { Perfil dos estudos sobre } \\
\text { avaliação da postura } \\
\text { corporal em escolares: } \\
\text { duas décadas de } \\
\text { pesquisas brasileiras }\end{array}$ & Menção Honrosa & $\begin{array}{l}\text { NICHELE, L. F. I.; } \\
\text { TURRA, P.; } \\
\text { BADARÓ, A. F. }\end{array}$ \\
\hline $\begin{array}{l}2014 \\
\text { Congresso } \\
\text { Internacional } \\
\text { Posturologia } \\
\text { Fisioterapia } \\
\text { Sorocaba/SP }\end{array}$ & $\begin{array}{l}\text { Alterações da postural } \\
\text { corporal em crianças }\end{array}$ & $\begin{array}{l}\text { Resumo Premiado } \\
\text { Modalidade Oral } \\
2^{\circ} \text { Lugar }\end{array}$ & $\begin{array}{l}\text { NICHELE, L. F. I.; } \\
\text { TURRA, P.; } \\
\text { BADARÓ, A. F. }\end{array}$ \\
\hline
\end{tabular}




\begin{tabular}{|c|c|c|c|c|}
\hline $\begin{array}{l}2014 \\
\text { Congresso } \\
\text { Internacional } \\
\text { Posturologia } \\
\text { Fisioterapia } \\
\text { Sorocaba/SP }\end{array}$ & $\begin{array}{r}\mathrm{de} \\
\mathrm{e}\end{array}$ & $\begin{array}{l}\text { Prevalência de afecções } \\
\text { na coluna vertebral em } \\
\text { trabalhadores adultos- } \\
\text { jovens de um Cerest/RS }\end{array}$ & $\begin{array}{l}\text { Resumo Premiado } \\
\text { Modalidade Poster } \\
1^{\circ} \text { Lugar }\end{array}$ & $\begin{array}{l}\text { COCCO, V. M.; } \\
\text { JESUS, H. A.; } \\
\text { BADARÓ, A. F. }\end{array}$ \\
\hline
\end{tabular}

Fonte: autora (2019).

Recebi homenagens de reconhecimento pelo trabalho realizado no ensino e na assistência com a fisioterapia em alguma ocasião. Em 1986 a coordenação do curso de Fisioterapia homenageou seus docentes, na comemoração dos 20 anos do curso. Em 2015 fui homenageada pelo Crefito 5, RS, pelos 35 anos de atividade na profissão, com o prêmio Ruy Gallart de Menezes. Em 2019 o Departamento de Fisioterapia e Reabilitação, igualmente, reconheceu o trabalho dos seus docentes, na comemoração dos 40 anos do curso.

Fui professora homenageada em diversas turmas de formandos do curso de Fisioterapia da UFSM, Patronesse da Turma de 1994 e paraninfa da 59ª turma, em 2012.

\section{Participação em eventos nacionais e internacionais}

Participei de muitos eventos nacionais na forma de congressos, simpósios, fórum, oficinas e encontros. Também, para me manter atualizada, fiz parte de cursos de curta duração, de eventos nacionais e internacionais, apresentando trabalhos, discutindo temas em mesas redondas, coordenando apresentações de temas livres ou organizando cursos. Apresento, a seguir, alguns cursos de maior relevância entre os que participei no período de 2008-2018, quadro 14, e as palestras proferidas nesse mesmo período, quadro 15.

Quadro 14 -

Principais encontros e cursos de curta duração realizados.

\begin{tabular}{|c|l|l|l|l|}
\hline Ano & \multicolumn{1}{|c|}{ Evento CH } & \multicolumn{1}{|c|}{ Instituição } \\
\hline 2009 & $\begin{array}{l}\text { Encontro dos CEPs - encontro de } \\
\text { profissionais envolvidos no ensino da } \\
\text { bioética nos cursos de graduação da saúde }\end{array}$ & $\begin{array}{l}\text { VIII Congresso Brasileiro de } \\
\text { Bioética - Rio de Janeiro }\end{array}$ \\
\hline 2009 & $\begin{array}{l}\text { Seminários de Bioética } \\
\text { (módulos do Curso de Mestrado) }\end{array}$ & $\begin{array}{l}\text { Seminário de Investigação em Bioética } \\
2009\end{array}$ & $\begin{array}{l}\text { V Seminário Internacional e } \\
\text { Interuniversitário de biomedicina y derechos } \\
\text { humanos }\end{array}$ & $\begin{array}{l}\text { Universidad Complutense de } \\
\text { Madrid, UCM - Espanha }\end{array}$ \\
\hline 2009 & $\begin{array}{l}\text { Seminário Internacional Bioética e Saúde } \\
\text { Pública }\end{array}$ & $\begin{array}{l}\text { Universidad Complutense de } \\
\text { Madrid, UCM - Espanha }\end{array}$ \\
\hline 2010 & $\begin{array}{l}\text { Abordagem de Casos Clínicos em Bioética } \\
\text { Madrid, UCM - Espanha }\end{array}$ & $\begin{array}{l}\text { CCS- UFSM } \\
\text { PPG-Enfermagem }\end{array}$ \\
\hline 2012 & $\begin{array}{l}\text { XXII Fórum nacional de Ensino em } \\
\text { Fisioterapia }\end{array}$ & $\begin{array}{l}\text { Universidade Federal de Santa } \\
\text { Maria }\end{array}$ \\
\hline 2012 & $\begin{array}{l}\text { I Encontro GTs de Coordenadores dos } \\
\text { cursos Fisioterapia e TO do RS }\end{array}$ & Abenfisio \\
\hline Regae: Rev. Gest. Aval. Educ. Santa Maria & v. 10 & n. especial & e67494, p. 1-46 \\
\hline
\end{tabular}




\begin{tabular}{|l|l|l|ll|}
\hline 2014 & $\begin{array}{l}\text { II Seminário internacional de Bioética e } \\
\text { Saúde Pública: desafios e perspectivas }\end{array}$ & $40 \mathrm{~h}$ & Depe - Husm - UFSM & \\
\hline 2014 & IX Congresso Brasileiro de Queimaduras & $24 \mathrm{~h}$ & $\begin{array}{l}\text { Sociedade Brasileira de } \\
\text { Queimaduras }\end{array}$ & de \\
\hline
\end{tabular}

Fonte: autora (2019).

Quadro 15 -

Palestras proferidas em eventos científicos (2008-2018).

\begin{tabular}{|c|c|c|}
\hline Ano & Tema & Evento /instituição \\
\hline 2009 & A bioética no âmbito das profissões & V Seminário de Ética - Confef \\
\hline 2009 & $\begin{array}{l}\text { Reflexões metodológicas sobre a ética nas } \\
\text { pesquisas em saúde }\end{array}$ & $\begin{array}{l}\text { JAI - UFSM: ética na pesquisa } \\
\text { envolvendo seres humanos }\end{array}$ \\
\hline 2009 & $\begin{array}{l}\text { Ética na pesquisa: análise das questões que } \\
\text { envolvem a ética na pesquisa, filme Cobaias }\end{array}$ & Depe - Husm \\
\hline 2010 & $\begin{array}{l}\text { Correlações biomecânicas da cintura escapular, } \\
\text { caixa torácica e coluna vertebral }\end{array}$ & $\begin{array}{l}\text { XXV Semana Acadêmica de } \\
\text { Fisioterapia - UFSM }\end{array}$ \\
\hline 2010 & $\begin{array}{l}\text { Reeducação Postural global } \\
\text { conceituais }\end{array}$ & $\begin{array}{l}\text { Ciclo de palestras: } \\
\text { Curso de Fisioterapia - UFSM }\end{array}$ \\
\hline 2011 & $\begin{array}{l}\text { Conflitos Éticos observados na prática profissional } \\
\text { dos fisioterapeutas }\end{array}$ & $\begin{array}{l}\text { I Congresso Internacional de } \\
\text { Fisioterapia, Ética e Bioética }\end{array}$ \\
\hline 2011 & $\begin{array}{l}\text { Os referenciais básicos da bioética: suas } \\
\text { implicações na atualidade }\end{array}$ & $\begin{array}{l}\text { VIII Seminário Internacional de } \\
\text { Educação (São Sepé/RS) }\end{array}$ \\
\hline 2012 & A fisioterapia sob um olhar da bioética & $\begin{array}{l}\text { XXVII Semana Acadêmica do } \\
\text { Curso de Fisioterapia UFSM }\end{array}$ \\
\hline 2013 & RPG no tratamento da hérnia de disco & Afism \\
\hline 2014 & $\begin{array}{l}\text { Fisioterapia no paciente hospitalar: da internação } \\
\text { a alta }\end{array}$ & $\begin{array}{l}\text { IX Congresso } \\
\text { Queimaduras }\end{array}$ \\
\hline 2018 & Bioética na atuação fisioterapêutica & $\begin{array}{l}\text { XXII Semana Acadêmica da } \\
\text { Fisioterapia }\end{array}$ \\
\hline
\end{tabular}

Fonte: autora (2019).

\section{Coordenador de projetos de pesquisa}

Os projetos de pesquisa que desenvolvi aconteceram em parceria com os acadêmicos do curso e realizados de forma inter e multidisciplinares, em conjunto com outros colegas da área. Muitos desses estudos foram desenvolvidos a partir da prática assistencial da Fisioterapia no Husm, outros são decorrentes dos campos extensionistas, principalmente o de acompanhamento do desenvolvimento postural de crianças e adolescentes em seu ambiente escolar. Alguns centros de saúde, como o Cerest e o Instituto de Radiologia São Lucas, nos proporcionaram coleta de dados, cedendo seus espaços e disponibilizando os arquivos. As revisões de literatura e os estudos de ética e bioética na fisioterapia, também fizeram parte da temática desses projetos.

No quadro 16 estão listados os projetos de pesquisa, desenvolvidos no período de 2008 a 2018, de acordo com o período de realização, título, número de registro no SIE e minha função como coordenadora, co-orientadora ou participante. 
Quadro 16 -

Coordenador, orientador ou participante de projetos de pesquisa.

\begin{tabular}{|l|l|l|l|}
\hline Período & \multicolumn{1}{|c|}{ Projeto } & \multicolumn{1}{|c|}{ Atuação } \\
(número)
\end{tabular}




\begin{tabular}{|l|l|l|l|}
\hline 2009-2012 & $\begin{array}{l}\text { Correlação entre desvios posturais da coluna } \\
\text { vertebral e o posicionamento pélvico analisado } \\
\text { através de radiografia panorâmica de perfil }\end{array}$ & $\begin{array}{l}\text { coordenador / } \\
\text { orientador }\end{array}$ & 031052 \\
\hline $2006-2011$ & Ética e Bioética na práxis da Fisioterapia & coordenador & 019763 \\
\hline
\end{tabular}

Fonte: autora (2019).

\section{Projetos e programa de extensão}

Nos anos 1980 as ações extensionistas passaram a ser estimuladas na instituição, para se associar ao ensino e à pesquisa. No Centro de Ciências da Saúde, acadêmicos e docentes dos cursos de Medicina, Odontologia, Enfermagem, Farmácia e Fisioterapia elaboraram o projeto intitulado Ação comunitária na Cidade dos Meninos - registro n. 661, 1992 - com o intuito de integrar ações preventivas em saúde de forma multidisciplinar. O objetivo era se dissociar do modelo hospitalocêntrico, focado somente em práticas assistenciais, curativas de ensino e pesquisa centradas no hospital. Esse projeto foi desenvolvido em uma instituição filantrópica religiosa, que atendia crianças carentes em regime de internato. Ali atuei com a fisioterapia durante dez anos (1988-1998), frequentando o local uma vez por semana. A parceria com a enfermagem foi fundamental para o meu desenvolvimento nestas ações.

Resumo do projeto Ação comunitária na Cidade dos Meninos: Objetivo: desenvolver através de um trabalho multiprofissional atividades comunitárias, buscando uma integração com a comunidade, respeitando e valorizando a realidade existente, para juntos chegar a resolutibilidade. Justificativa: o Centro de Ciências da Saúde da UFSM, através de seus cursos vem desenvolvendo há quatro anos um trabalho comunitário e multidisciplinar na Cidade dos Meninos, Santa Maria/RS. No início do trabalho tentou se integrar todos os cursos do CCS no projeto, mas apenas os cursos de enfermagem, fisioterapia e medicina conseguiram desenvolver o trabalho proposto, os outros participaram ou participam de forma isolada. No momento em que todos tomaram consciência dos problemas da cidade dos meninos e buscaram juntos uma forma de solucioná-lo, fica evidenciado que saúde é uma parte resultante do contexto vivenciado e que deve ser tratado da mesma forma que os outros problemas.

A partir dessa experiência, desenvolvi outros projetos, focados na fisioterapia. No quadro 17, destaco aqueles que deram suporte para a realização do Programa de Extensão.

Quadro 17 -

Principais projetos de extensão que deram suporte ao Programa de Extensão.

\begin{tabular}{|c|l|c|}
\hline Número de registro & \multicolumn{1}{|c|}{ Título } & Período \\
\hline 10167 & $\begin{array}{l}\text { Levantamento de alterações posturais em escolares } \\
\text { do Ensino Fundamental }\end{array}$ & $2000-2006$ \\
\hline 10997 & $\begin{array}{l}\text { Má postura: ensinando comunidade escolares a } \\
\text { preveni-las }\end{array}$ & $2001-2002$ \\
\hline 023952 & $\begin{array}{l}\text { Fisioterapia no crescimento e no desenvolvimento } \\
\text { corporal de escolares }\end{array}$ & $2009-2010$ \\
\hline 026505 & $\begin{array}{l}\text { Avaliação postural e cuidados posturais em escolares } \\
\text { do Ensino Fundamental }\end{array}$ & $2010-2013$ \\
\hline
\end{tabular}

Fonte: autora (2019). 


\section{Programa de extensão}

Os projetos extensionistas e de pesquisa que vínhamos desenvolvendo com a saúde do escolar, junto com as práticas de ensino na disciplina Fisioterapia na Saúde do Escolar" - FSR1021, levaram-nos a organizar o Programa de fisioterapia no cuidado corporal de escolares - projeto número 031599 -, o qual teve início em março de 2012, com duração de cinco anos, sob minha coordenação. Esse programa se manteve com recursos financeiros e o auxílio de duas bolsas anuais do Fiex/CCS, além de acadêmicos voluntários. Participaram dele um total 14 estudantes de graduação da Fisioterapia, os quais, além da prática extensionista, envolveram-se com a pesquisa e a divulgação desse trabalho em eventos científicos.

Em resumo, a proposta do programa era: as ações desenvolvidas pela Fisioterapia visam integrar-se ao trabalho da equipe multidisciplinar, formada por pedagogos, educadores físicos, assistente social, psicólogos, dentistas, médicos, educadores, fonoaudiólogos, voluntários e familiares. A proposta da atenção fisioterapêutica está centrada nas questões que envolvem a postura corporal e no acompanhamento do crescimento e do desenvolvimento físico de escolares na faixa etária entre 6 e 12 anos, frequentadores da instituição filantrópica Cefasol. Inicialmente, realizam-se as avaliações postural, antropométrica e fotogramétrica. De acordo com os resultados dessas avaliações, os escolares são agrupados por faixa etária, sexo e, considerando, as alterações posturais detectadas. As atividades são realizadas de forma lúdica, compreendendo alongamento, relaxamento e consciência corporal. Os grupos são trabalhados durante uma hora por semana. Aqueles que apresentam problemas físicos e/ou motores mais sérios são encaminhados para um ambulatório de fisioterapia para tratamento individualizado. Ainda, realizam-se orientações sobre higiene pessoal, cuidados alimentares, cuidados para a manutenção da boa postura, por meio de palestras, temas educativos, filmes, desenhos e jogos. A fisioterapia procura difundir essas orientações aos familiares e educadores. Os resultados preliminares em projetos de pesquisa e extensão, demonstraram mudanças no comportamento das crianças quanto aos cuidados com o corpo, diminuição das tensões e dores musculares, resultando em maior flexibilidade corporal. Ainda, as crianças trabalhadas com bolas suíças diminuíram o grau de agressividade. Diante disto, espera-se que o programa proposto possa ampliar a atuação da fisioterapia naquele local, e difundir essa proposta para as escolas.

Os resultados obtidos com esse programa foram além das expectativas. O envolvimento dos alunos foi grande e reconhecido pela comunidade envolvida. Os trabalhos acadêmicos desenvolvidos proporcionaram, aos alunos, a participação em inúmeros eventos nacionais, internacionais e locais. Ainda, o Programa foi palco para a realização de TCCs de graduação, monografias de especialização e uma dissertação de Mestrado. Consequentemente, os resultados alcançados deram visibilidade à fisioterapia, por meio das publicações em eventos e periódicos científicos e por intermédio dos prêmios recebidos.

Gestão: cargos de coordenação, chefias de curso, departamento e serviços

O envolvimento com as atividades administrativas do curso aconteceu cedo na minha carreira docente. Em dezembro de 1980 fui convocada a substituir o coordenador 
do curso, tendo como principal tarefa a realização da colação de grau da segunda turma. Foi mais um grande desafio, para quem estava ainda em fase de adaptação à docência, à instituição e à cidade. No ano de 1982 assumi, por indicação da coordenação do curso, a chefia do Serviço de Fisioterapia pelo período de meses. Em 1983 fui substituta da chefia do Departamento de Fisioterapia e Reabilitação. Em 1986 fui eleita para a chefia do Serviço de Fisioterapia do Husm, cargo em que atuei por dois anos. Nessa mesma década coordenei os estágios curriculares da Fisioterapia nos anos de 1984, 1985, 1986 e 1988. Também participei das comissões para realizar a primeira reforma curricular do curso e de estudos para implantação de laboratório de fisioterapia. Representei o curso na Comissão de Extensão do CCS e na Comissão de Extensão do Curso.

Ainda, fui vice-coordenadora do curso de Fisioterapia, eleita para a gestão 19901992, sob a coordenação da prof ${ }^{a}$ Eliane Correia. Mais tarde, após concluir meus estudos de Doutorado, passei a me envolver com a criação do curso de especialização para a Fisioterapia, o que foi obtido em 2011. Assumi a coordenação dele na gestão 2011-2014.

No que se refere ao período 2008-2018, apresento a seguir, as portarias referentes ao exercício na coordenação do Curso de Especialização em Reabilitação Físico Motora: portaria n. 027/2011- CCS, de 18 de abril de 2011; portaria n. 144 CCS, de 04 de janeiro de 2014; portaria n. 116/CCS, de 19 de agosto de 2014, que encerra as atividades na coordenação.

\section{Representação: órgãos colegiados ou comissões permanentes das unidades universitárias}

A participação em órgãos colegiados e em comissões sempre fez parte de minhas atividades acadêmicas. No Departamento de Fisioterapia e Reabilitação sou integrante efetivo e participante do colegiado departamental, desde o início da carreira docente até os dias de hoje. Nos outros órgãos institucionais a participação aconteceu por vínculo a cargos ocupados ou por indicação para representar categorias. No período de 2008 a 2018 participei das seguintes comissões permanentes:

a) Conselho do Centro de Ciências da Saúde, maio 2011 - julho 2014, titular na condição de coordenadora do Cerfm.

b) Colegiado do Curso de Especialização em Reabilitação Físico Motora, maio 2011 - julho 2014, presidente na condição de coordenadora do Cerfm.

c) Colegiado do Curso de Especialização em Reabilitação Físico Motora, portaria n. 120/CCS, de 25 de agosto 2014, suplente.

d) Comitê de Ética em Pesquisa do CCS, portaria n. 061/2000-CCS, de 9 de agosto 2000.

d) Comitê de Ética em Pesquisa da UFSM, portaria n. 46.767, de 29 de setembro de 2004; portaria n. 54.279, de 2 de fevereiro de 2009; portaria n. 65.043, de 18 de março 2013.

e) Comitê de Bioética do Hospital Universitário de Santa Maria, portaira n. 007, de maio de 2010, da direção-geral do Husm, período: maio de 2010 a abril de 2011.

\section{Comissões temporárias das unidades universitárias}

a) Comissão de Criação do Curso de Especialização em Fisioterapia, portaria n. 092/10-CCS, de 29 de setembro de 2010. 
b) Grupo de discussões para a implantação do Comitê de Bioética para o Husm, organização da Depe/Husm, apostila à portaria n. 54.279, de 2 de fevereiro de 2009, período: março de 2009 - maio de 2010.

c) Comissão Organizadora do Ciclo de Palestras do Curso de Fisioterapia, portaria n. 046 /2010-CCS, de 8 de agosto de 2010, período: 2010-2011.

d) Curso A abordagem de casos clínicos sob o ponto de vista da bioética, 19 a 23 de janeiro de 2010: participante da comissão organizadora.

e) Comissão de seleção de candidatos ao curso de especialização em Reabilitação Físico Motora, portaria n. 059/2011-CCS, de 8 de junho de 2011.

\section{Núcleo Docente Estruturante - NDE}

Sempre estive envolvida com as questões curriculares do nosso curso, participando, de forma ativa, das reformas curriculares, de adequações de disciplinas, dos estágios e de conteúdos programáticos. Fui integrante da comissão de reforma curricular do curso de Fisioterapia em 1984, 1992, 2004 e 2015. Atuei no NDE em dois momentos:

a) Núcleo Docente Estruturante do Curso de Fisioterapia, portaria n. 047/CCS, de 15 de maio de 2012, período: 2012-2016.

b) Núcleo Docente Estruturante do Curso de Fisioterapia, portaria n. 042/CCS, de 27 de março de 2018, período: 2018-2019.

\section{Bancas de dissertação e monografias}

Em 2011 participei da banca de dissertação de mestrado de Patrícia Girard, sob a orientação da prof $^{\mathrm{a}}$ dr ${ }^{\mathrm{a}}$ Carolina Lisboa Mezzomo, no curso de pós-graduação em Distúrbios da Comunicação Humana, CCS/UFSM. No período de 2018 a 2018 fiz parte de 13 bancas de monografia do curso e especialização em Reabilitação Físico Motora, as quais estão listadas na Tabela 18.

Quadro 18 -

Participação em bancas de monografia do Curso e Especialização em Reabilitação

Físico Motora.

\begin{tabular}{|c|c|c|}
\hline Ano & Monografia & Acadêmicos \\
\hline 2016 & $\begin{array}{l}\text { Perfil da Postura Corporal em idosos: revisão } \\
\text { narrativa }\end{array}$ & Deyze lop Tavares \\
\hline 2015 & $\begin{array}{l}\text { Avaliação Postural em Escolares: um estudo } \\
\text { longitudinal }\end{array}$ & $\begin{array}{l}\text { Lidiane de Fátima } \\
\text { Nichelle }\end{array}$ \\
\hline 2015 & $\begin{array}{l}\text { Avaliação da Qualidade de Vida de pacientes com } \\
\text { escoliose idiopática }\end{array}$ & Patricia Turra \\
\hline 2015 & $\begin{array}{l}\text { Tipos de pé em bailarinas clássicas e sua relação } \\
\text { com algias e lesões musculoesqueléticas }\end{array}$ & Ariane Alves Jacobson \\
\hline 2014 & $\begin{array}{l}\text { Investigação de histórico de trabalho infantil em } \\
\text { trabalhadores assistido em um Cerest }\end{array}$ & Vanessa Michelon Cocco \\
\hline 2013 & $\begin{array}{l}\text { A influência de um programa de exercícios com bolas } \\
\text { suíças sobre a flexibilidade de escolares }\end{array}$ & Tatiele Zulian \\
\hline 2013 & $\begin{array}{l}\text { Investigação da escoliose idiopática em crianças e } \\
\text { adolescentes: revisão sistemática }\end{array}$ & $\begin{array}{l}\text { Mithielle } \\
\text { Machado }\end{array}$ \\
\hline
\end{tabular}




\begin{tabular}{|l|l|l|}
\hline 2012 & $\begin{array}{l}\text { Avaliação estática do posicionamento escapular em } \\
\text { pacientes em período pré-operatório de construção do } \\
\text { manguito rotator }\end{array}$ & Veronica Ilha Zimmer \\
\hline 2012 & $\begin{array}{l}\text { Correlação entre desvios posturais da Coluna } \\
\text { vertebral e posicionamento pélvico, analisado através } \\
\text { da radiografia panorâmica de perfil }\end{array}$ & Laura Menezes Weber \\
\hline 2012 & $\begin{array}{l}\text { Dor Lombar em adolescentes: ocorrência e } \\
\text { características }\end{array}$ & $\begin{array}{l}\text { Monica Renata de Oliveira } \\
\text { G. da Costa Moura e Silva }\end{array}$ \\
\hline 2012 & $\begin{array}{l}\text { Postura Corporal de idosos integrantes de grupo de } \\
\text { atividade física }\end{array}$ & Andrea Souza Buzatti \\
\hline 2012 & $\begin{array}{l}\text { Relação entre postura corporal de bailarinas e } \\
\text { movimento de balé clássico }\end{array}$ & $\begin{array}{l}\text { Estele Caroline Welter } \\
\text { Meereis }\end{array}$ \\
\hline $\begin{array}{l}\text { Tração contínua mecânica no tratamento da dor } \\
\text { lombar: revisão sistemática }\end{array}$ & Emilma Forgliarini \\
\hline
\end{tabular}

Fonte: autora (2019).

\section{Bancas de trabalhos de conclusão de curso}

A participação em bancas de TCCs no Curso de Fisioterapia da UFSM sempre foi uma constante das minhas atividades docentes. No total foram vinte. No período de 20082018 houve uma redução para seis bancas, em que onze acadêmicos apresentaram seus estudos para a conclusão do curso. Esses dados estão apresentados no quadro 19.

Tabela 19 -

Bancas de TCCs no curso de Fisioterapia da UFSM (2008-2018).

\begin{tabular}{|c|c|c|}
\hline Ano & Monografia & Acadêmicos \\
\hline 2015 & $\begin{array}{l}\text { Tipo de pé e a distribuição de carga corporal em } \\
\text { estudantes universitárias }\end{array}$ & $\begin{array}{l}\text { Andressa Hardt de Jesus } \\
\text { Marina Teixeira Trevisan }\end{array}$ \\
\hline 2014 & $\begin{array}{l}\text { Caracterização do perfil postural de escolares } \\
\text { frequentadores de uma instituição filantrópica }\end{array}$ & $\begin{array}{l}\text { Patricia Turra } \\
\text { Lidiane de Fátima llha } \\
\text { Nichelle }\end{array}$ \\
\hline 2013 & Avaliação Postural de escolares: revisão sistemática & Tielen Dias Marques \\
\hline 2013 & $\begin{array}{l}\text { Efeitos da liberação miofascial sobre a funcionalidade, } \\
\text { dor e equilíbrio da mulher mastectomizada }\end{array}$ & $\begin{array}{l}\text { Gustavo N. Peter } \\
\text { Tarciso da S. Santos } \\
\text { Daniel Dalla Nora }\end{array}$ \\
\hline 2012 & $\begin{array}{l}\text { Descrição da Flexibilidade, IMC, e queixas de dor em } \\
\text { crianças em idade escolar }\end{array}$ & Êmile dos Santos \\
\hline 2010 & $\begin{array}{l}\text { Correlação entre desvios posturais da coluna vertebral } \\
\text { e o posicionamento pélvico analisado através de } \\
\text { radiografia panorâmica de perfil }\end{array}$ & $\begin{array}{l}\text { Cintia Ulguim } \\
\text { Paola Hahn }\end{array}$ \\
\hline
\end{tabular}

Fonte: autora (2019).

\section{Comissões de avaliação de cursos superiores Sesu/MEC}

No início dos anos 1980 existiam poucos cursos de Fisioterapia no Brasil, a profissão estava em processo de crescente evolução e reconhecimento. No decorrer da referida década novos cursos foram surgindo exponencialmente, o que se repetiu nas décadas seguintes. Meu vínculo com uma instituição federal me levou a ser muito 
requisitada, pelo Sesu/MEC, para avaliar in loco a implantação de novos cursos e o reconhecimento daqueles que estavam em fase de concluir a sua primeira turma de formandos.

Desse modo, em 1983 participei, junto com o prof. José Américo da Silva, da PUCamp, da minha primeira experiência com a análise de um curso para o seu reconhecimento. Fomos avaliar os cursos de Fisioterapia e Terapia Ocupacional da Universidade Federal de Minas Gerais. A partir daí fui chamada, inúmeras vezes, para participar de processos como esse.

De 1983 a 200, participei de dez comissões para avaliação de cursos de Fisioterapia. No início do milênio houve mudanças no MEC, com ampliação do cadastro dos docentes avaliadores, para atender à demanda das reavaliações dos cursos de Fisioterapia e de Terapia Ocupacional. Nessa época optei por não me credenciar para continuar as avaliações, uma vez que estava empenhada em me preparar para o doutorado.

\section{Considerações finais}

Tomar a iniciativa de escrever esse memorial me custou muitas indagações, reflexões sobre o que escrever e como relatar meu processo histórico na docência com a Fisioterapia. Tive o incentivo de muitos colegas que já passaram por essa experiência, os quais me instigaram a escrevê-lo, dizendo-me que não deveria deixar de fazer esse relato. Outras pessoas e amigos, que conhecem minha história pessoal e docente e que compartilharam parte dessa minha trajetória, deixaram claro que eu tinha o dever de registrar esse processo, trilhado junto ao surgimento e à evolução da Fisioterapia, o qual vivenciei.

Confesso que não foi fácil escrever esse memorial, uma vez que muitos acontecimentos pessoais e de trabalho me fizeram recuar e até pensar em desistir. Mas resisti, enfrentei as dificuldades e aqui estou, finalizando o relato da minha participação na construção dessa profissão, por meio de estudos, do ensino, da assistência, das lutas de classe, profissional e acadêmica, na Fisioterapia.

Voltar ao passado e reviver todo esse processo que percorri durante os 40 anos de profissão dedicados ao curso de Fisioterapia foi, ao mesmo tempo, difícil e prazeroso. A dificuldade esteve em listar, organizar e valorizar trabalhos realizados que, de certa forma, entendo como uma obrigação do ofício e não como algo a ser glorificado. Dúvidas sobre o que seria realmente relevante? Elas surgiram, sim, já que tudo o que fiz e em tudo o que investi foi por entender que era importante para o meu crescimento pessoal, cultural e científico e, assim, relevantes de serem compartilhados com as demais pessoas envolvidas com a nossa profissão. Desde uma simples participação ouvindo uma palestra, como escutar um paciente, tirar dúvidas de um aluno, ou no empenho para superar ações mais complexas, como me preparar para o Mestrado e para o Doutorado e o seu consequente desenvolvimento e conclusão, tudo isso teve o mesmo valor para o meu aprendizado, pois cada fato estava intrinsecamente vinculado ao outro.

Dessa forma, escrever esse memorial teve o sabor de reviver cada etapa desse passado, suas conquistas e derrotas que, com o tempo, muito havia se perdido na minha memória. Por outro lado, igualmente, significou constatar que nada foi em vão, que todo o esforço valeu a pena. 
Como profissional da saúde procurei nessa caminhada relacionar o processo de saúde ao educativo junto às ações assistenciais e preventivas, direcionadas aos cuidados do movimento corporal em todas as fases do desenvolvimento humano. Assim, como pode ser constatado nesse memorial, minha formação acadêmica não teve uma trajetória linear, em uma determinada linha de pesquisa ou em uma área específica do conhecimento científico. O que sempre esteve em foco, em meu trabalho, foi o movimento humano, que é o objeto de estudo da Fisioterapia. Mais especificamente o movimento articular. A partir daí, minha prática na Fisioterapia, com ênfase na reabilitação do movimento corporal, me levou a buscar cursos os quais me capacitassem a entender o indivíduo além do seu corpo, para compreender o quanto a dinâmica corporal estava vinculada a outros fatores, além do corpo físico, relacionados ao seu meio ambiente, à sua cultura, ou seja, ao ser bio, psíquico, social.

No início de minha carreira os encontros científicos na Fisioterapia eram incipientes. A participação em discussões e em eventos com profissionais de outros cursos da saúde, bem como de outras áreas de conhecimentos, como as Ciências Sociais, as Ciências Humanas, e mesmo as Ciências Exatas, levaram-me a realizar uma escalada pausada na pós-graduação, com intervalos longos, mas necessários para que pudessem ser absorvidos, refletidos e praticados. A vertente indagadora constantemente esteve presente nas minhas ações sobre as questões de saúde, assim como a busca por conhecimentos que fundamentassem reflexões mais profundas sobre o ser humano, como um todo.

O curso de Especialização em Saúde Coletiva me direcionou as práticas assistenciais de promoção e de prevenção em saúde para além das atividades fisioterapêuticas. Com o tempo isso gerou a necessidade de desenvolver ações educativas, o que me fez buscar o Mestrado em Educação. Essas vivências em saúde, de forma a buscar a conscientização das pessoas para terem domínio do seu autocuidado, geraram reflexões sobre as questões que envolvem a autonomia dos indivíduos. Em função disso passei a buscar conhecimentos acerca da Ética e, consequentemente, da Bioética quando, então, resolvi realizar o Doutorado em Bioética, o que me proporcionou associar toda a vivência obtida com a Fisioterapia, a saúde pública e a educação, com essa nova aérea de conhecimento que estava surgindo. $E$ assim passei a agregar essas reflexões mais abrangentes ao campo da Fisioterapia.

Desse modo, ao longo desse caminho, pude exercitar esses diversos conhecimentos, num contexto de aquisição e de rompimento do saber adquirido. Com base em muita reflexão sobre a prática desenvolvida no exercício da docência e da assistência é que cheguei até aqui, contudo, sem ter uma finalização, pois esse é um movimento contínuo, ininterrupto, disponível sempre para contribuir com a reflexão com a formação do fisioterapeuta.

Logo, com esse memorial busquei mostrar essa trajetória, de forma humilde, sem grandes pretensões com as demandas quantitativas e qualitativas de produções científicas, hoje tão valorizadas e cobradas em nossa academia. Entretanto, essa caminhada diferenciada, em busca da pluralidade de saberes, esteve sempre atrelada ao exercício da docência, integrando as atividades de ensino, assistência, administração, gestão e pesquisa, as quais fortaleceram o desenvolvimento da Fisioterapia, área de minha atuação. 
Agradeço, imensamente, a todas as pessoas que fizeram parte dessa caminhada: meus professores, meus colegas, meus alunos, meus amigos, meus familiares e os desconhecidos. Sem a presença de todos vocês, nada do que consegui fazer seria possível.

Gratidão, também, a essa grande instituição de ensino, UFSM, que a todos acolhe sem distinção!

Para finalizar, deixo aqui alguns versos de Milton Nascimento (1978), que sintetizam o que me parece ser o ato de viver e minha trajetória nestes muitos anos de atuação na Fisioterapia:

$$
\begin{gathered}
\text { "É preciso ter força, É preciso ter raça... } \\
\text { É preciso ter gana... sempre } \\
\text { Qualquer maneira de amor vale a pena } \\
\text {.....é preciso ter sonho, ...sempre... } \\
\text {... o que importa é ouvir a voz do coração" }
\end{gathered}
$$

\section{Referências}

NASCIMENTO, Milton; BRANT, Fernando. Maria, Maria. In: NASCIMENTO, Milton, Clube da esquina 2. Rio de Janeiro: Record, 1978.

UFSM. Resolução n. 013/2014. Santa Maria: UFSM, 2014.

MEC. Diretrizes curriculares para os cursos de graduação em Fisioterapia. Brasília: MEC, 2002.

Ana Fátima Viero Badaró é professora na Universidade Federal de Santa Maria.

Orcid: http://orcid.org/0000-0002-8848-6994.

Endereço: Avenida Roraima, 1000 - 97105-900 - Santa Maria - RS - Brasil.

E-mail: badaroana@uol.com.br.

Critérios de autoria: Ana Fátima Viero Badaró concebeu o texto na sua integralidade.

Recebido em 31 de agosto de 2021.

Aceito em 19 de outubro de 2021. 